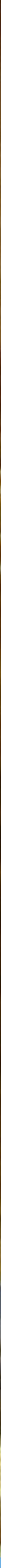

Handelingsperspectief voor pluimveehouders in de preventie van laag- en hoogpathogene vogelgriep (AI)

Martien Bokma, Ron Bergevoet, Armin Elbers, Jeanet van der Goot, Francesca Neijenhuis, Thea van Niekerk, Ferry Leenstra

\title{
WAGENINGEN
}

UNIVERSITY \& RESEARCH 



\section{Handelingsperspectief voor pluimveehouders in de preventie van laag- en hoogpathogene vogelgriep (AI)}

Martien Bokma ${ }^{1}$, Ron Bergevoet ${ }^{2}$, Armin Elbers ${ }^{3}$, Jeanet van der Goot ${ }^{3}$, Francesca Neijenhuis ${ }^{1}$, Thea van Niekerk ${ }^{1}$, Ferry Leenstra ${ }^{1}$

1 Wageningen Livestock Research

2 Wageningen Economic Research

3 Wageningen BioVeterinary Research

Dit onderzoek is uitgevoerd door Wageningen Livestock Research, in opdracht van en gefinancierd in het kader van het publiek-private samenwerkingsproject 'Poultry4Food' binnen de Topsector Agri\&Food (TKI-AF-12048; BO-22.04-003-011)

Wageningen Livestock Research

Wageningen, december 2016

Rapport 998 
Bokma, Martien, Ron Bergevoet, Armin Elbers, Jeanet van der Goot, Francesca Neijenhuis, Thea van Niekerk en Ferry Leenstra, 2016. Handelingsperspectief voor pluimveehouders in de preventie van laag- en hoogpathogene vogelgriep (AI). Wageningen Livestock Research, Rapport 998.

Samenvatting NL Op verzoek van de pluimveesector is onderzoek uitgevoerd naar handelingsperspectief voor preventie van AI-insleep op legpluimveebedrijven, op basis van bestaande kennis. De bevindingen zijn in twee delen weergegeven: deel I met concrete adviezen voor pluimveehouders, en in deel II de onderbouwing met een samenvatting van bestaande kennis op het gebied van risicofactoren, preventieve maatregelen, vroegdetectie en mogelijkheden voor bevorderen van gewenst (preventief) gedrag.

Summary UK Committed by the Dutch poultry sector research is carried out concerning acting perspective for prevention of AI-introduction on poultry farms, based on existing knowledge. The findings are shown in two parts: part I with practical advices for poultry farmers, and part II with its underpinning with a summary of existing knowledge of risk factors, preventive measures, early detection and possibilities for promoting desired (preventive) behaviour.

Dit rapport is gratis te downloaden op http://dx.doi.org/10.18174/401482 of op www.wur.nl/livestock-research (onder Wageningen Livestock Research publicaties).

\section{(C) 2016 Wageningen Livestock Research}

Postbus 338, 6700 AH Wageningen, T 03174839 53, E info.livestockresearch@wur.nl, www.wur.nl/livestock-research. Wageningen Livestock Research is onderdeel van Wageningen University \& Research.

Wageningen Livestock Research aanvaardt geen aansprakelijkheid voor eventuele schade voortvloeiend uit het gebruik van de resultaten van dit onderzoek of de toepassing van de adviezen.

Alle rechten voorbehouden. Niets uit deze uitgave mag worden vermenigvuldigd en/of openbaar gemaakt worden door middel van druk, fotokopie, microfilm of op welke wijze dan ook zonder voorafgaande toestemming van de uitgever of auteur.

De certificering volgens ISO 9001 door DNV onderstreept ons kwaliteitsniveau. Op als onze onderzoeksopdrachten zijn de Algemene Voorwaarden van de Animal Sciences Group van toepassing. Deze zijn gedeponeerd bij de Arrondissementsrechtbank Zwolle. 


\section{Inhoud}

$\begin{array}{ll}\text { Woord vooraf } & 5\end{array}$

$\begin{array}{ll}\text { Samenvatting } & 7\end{array}$

1

\begin{tabular}{l|l} 
Inleiding & 8
\end{tabular}

DEEL I HANDELINGSPERSPECTIEF

$\begin{array}{ll}\text { Handelingsperspectief voor pluimveebedrijven } & 12\end{array}$

2.1 Vertaalslag biosecurity 'op maat' voor bedrijf: waar zit handelingsperspectief 12

$\begin{array}{ll}2.1 .1 & \text { Indeling in risicozones } \\ & 12\end{array}$

2.2 Optimale inrichting bedrijfsterrein (bij nieuwbouw, verbouw) 13

2.3 Handelingsperspectief in bestaande situaties $\quad 14$

2.3.1 Specifiek handelingsperspectief in de vrije uitloop $\quad 19$

$\begin{array}{ll}\text { 2.3.2 Meer belang bij goede biosecurity } & 20\end{array}$

$\begin{array}{lll}2.4 & \text { Vroegdetectie: handelingsperspectief } & 21\end{array}$

2.5 Handelingsperspectief voor ondersteunen preventief gedrag pluimveehouders 21

4.1 Bestaande kennis HPAI-uitbraken $\quad 26$

$\begin{array}{ll}\text { 4.1.1 HPAI in Nederland } & 26\end{array}$

$\begin{array}{ll}\text { 4.1.2 Recente uitbraken HPAI in de USA } & 27\end{array}$

4.2 Bestaande kennis LPAI-uitbraken en inzichten uit lopend onderzoek (Nederland) 30
4.2.1 Case-control studie Nederland 30

$\begin{array}{lll}4.3 & \text { Vroegdetectie van LPAI } & 30\end{array}$

4.4 De hygiënescan van de pluimveesector 32

$\begin{array}{lll}4.5 & \text { FAO 3-zone-biosecuritymodel } & 34\end{array}$

$5 \quad$ Kennis over bevorderen van gewenst (preventief) gedrag 36

$\begin{array}{lll}5.1 & \text { Sociaaleconomische criteria } & 36\end{array}$

$\begin{array}{lll}5.2 & \text { Gedragspsychologische aspecten } & 37\end{array}$

5.3 Samenhang in inzet van instrumenten $\quad 39$

$\begin{array}{ll}\text { Literatuur } & 41\end{array}$ 



\section{Woord vooraf}

De preventie van introductie van hoogpathogene (HPAI) en laagpathogene vogelgriep (LPAI) staat hoog op de beleidsagenda van de pluimveesector. Het belang van een versterkte preventie is nog eens benadrukt door uitbraken van vogelgriep op pluimveebedrijven rondom het openbaar maken van dit rapport, eind 2016. Helaas wordt de pluimveesector opnieuw met deze besmettelijke ziekte geconfronteerd. Een spannende tijd voor veel bedrijven.

De pluimveesector heeft binnen de PPS Poultry4Food aan Wageningen Livestock Research (WLR) gevraagd om handelingsperspectief voor preventie van AI-insleep op legpluimveebedrijven aan te geven op basis van bestaande kennis. Deze opdracht is door onderzoekers van WLR samen met onderzoekers van Wageningen Economic Research en Wageningen BioVeterinary Research afgestemd en uitgewerkt.

Het rapport bestaat uit twee delen. In het $2^{\mathrm{e}}$ deel wordt bestaande kennis samengevat op het gebied van risicofactoren, preventiemogelijkheden, vroegdetectie en mogelijkheden om gewenst (preventief) gedrag te ondersteunen. Voor pluimveehouders zal vooral het $1^{\mathrm{e}}$ deel van belang zijn, waarin mede op basis van de bestaande kennis concrete handvatten worden gegeven voor versterking van de insleeppreventie, op maat voor het bedrijf. Tevens wordt aangegeven hoe gewenst preventief handelen van pluimveehouders mogelijk kan worden ondersteund en bevorderd. Met een versterkte preventie zal niet alleen het risico op introductie van AI kunnen verminderen, maar ook het risico op insleep van andere schadelijke ziekteverwekkers.

Ik hoop dat het resultaat van dit onderzoek de pluimveesector handvatten geeft voor, daar waar mogelijk, het realiseren van een versterkte preventie met een verlaging van het risico van introductie van AI op pluimveebedrijven.

Annemarie Rebel

Hoofd afdeling Diergezondheid en Dierenwelzijn

Wageningen Livestock Research 


\section{Samenvatting}

De preventie van introducties van hoogpathogene (HPAI) en laagpathogene vogelgriep (LPAI), en het aangeven van handelingsperspectief voor pluimveehouders daarbij, staat hoog op de beleidsagenda van de pluimveesector. De pluimveesector heeft binnen de PPS Poultry4Food aan Wageningen Livestock Research (WLR) gevraagd om handelingsperspectief voor preventie van AI-insleep op (leg)pluimveebedrijven aan te geven op basis van literatuur en kennis die uit lopend onderzoek komt. Het onderzoek is uitgevoerd in afstemming met Wageningen Economic Research en Wageningen BioVeterinary Research.

De bevindingen zijn in twee delen weergegeven:

Deel I beschrijft het handelingsperspectief voor pluimveehouders en andere betrokkenen bij de sector voor een biosecurity-aanpak 'op maat' voor het bedrijf en het bevorderen daarvan. Tevens beschrijft het enkele relevante kennishiaten, en aanbevelingen voor aanpak ervan.

Voor versterking van de insleeppreventie vormt een indeling van het pluimveebedrijf in risicozones (rood-oranje/geel-groen) de rode draad. Voor bestaande situaties wordt in deel I per zone concreet handelingsperspectief aangegeven.

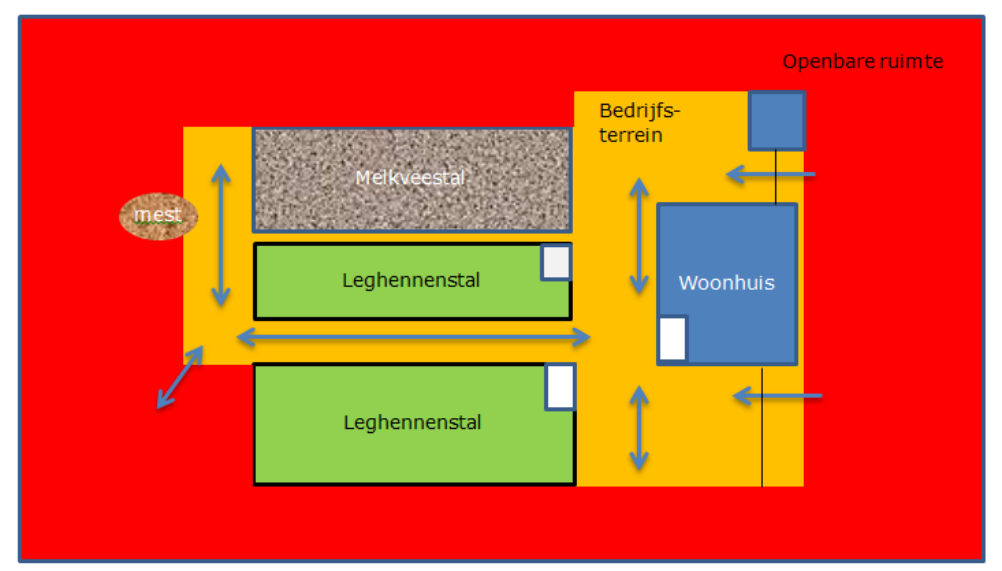

Figuur Voorbeeld onderverdeling van een bedrijfslocatie met leghennen en melkvee in risicozones

Deel II geeft een samenvatting van bestaande kennis op het gebied van risicofactoren, preventieve maatregelen, vroegdetectie en mogelijkheden voor bevorderen van gewenst (preventief) gedrag. Deze kennis is benut bij vaststellen van handelingsperspectief zoals beschreven in deel I. 


\section{$1 \quad$ Inleiding}

De preventie van introducties van hoogpathogene (HPAI) en laagpathogene vogelgriep (LPAI), en het aangeven van handelingsperspectief voor pluimveehouders daarbij, staat hoog op de beleidsagenda van de pluimveesector. Dit rapport richt zich op handelingsperspectief voor pluimveehouders en andere betrokkenen bij de sector met als doel preventie van introductie van vogelgriepvirus op pluimveebedrijven, en in het bijzonder op bedrijven met leghennen.

\section{Situatie}

Een HPAI-epidemie van subtype H7N7 vond plaats in 2003 in Nederland, waarbij 255 commerciële pluimveebedrijven besmet raakten en daarnaast 1255 commerciële pluimveebedrijven en kippen van 17421 hobbyhouders preventief werden geruimd. Tijdens de epidemie, die 2 maanden duurde, werden in totaal 30 miljoen kippen geruimd om de epidemie tot stilstand te brengen (Stegeman et al., 2004). Het virus besmette 89 mensen die in direct contact waren geweest met geïnfecteerde kippen en een dierenarts werkzaam in de bestrijdingscampagne overleed als gevolg van een infectie met het virus (Fouchier et al., 2004).

In het najaar van 2014 zijn drie leghenbedrijven, een vermeerderaar en een eendenbedrijf besmet geraakt met hoogpathogene aviaire influenza (HPAI; subtype H5N8) (Bouwstra et al., 2015). Dit betrof in alle gevallen bedrijven zonder vrije uitloop (in de vier daaraan gerelateerde beschermingsen toezichtsgebieden kwam slechts één bedrijf met vrije uitloop voor).

$\mathrm{Na}$ de HPAI-uitbraak in Nederland in 2003 zijn er enkele wettelijk verplichte meld- en waarschuwingssystemen ingesteld om een AI-besmetting zo snel mogelijk te detecteren (Elbers et al., 2007a): de serologische monitoring en de zogenaamde 'early warning'. De serologische monitoring bestaat uit verplicht bloedonderzoek op antistoffen tegen AI (ten minste 1 keer per jaar bij elk koppel of bedrijf; bij bedrijven met vrije uitloop moet dit onderzoek 4 keer per jaar worden uitgevoerd), en bij kalkoenen elke productieronde (Elbers et al., 2007b). De 'early warning' bestaat uit (Elbers et al., 2010): a) alertheid ten aanzien van de reguliere meldingsplicht; b) verplichte melding van verhoogde uitval boven bepaalde grenzen bij het meldpunt van NVWA; c) consulteren van de dierenarts bij daling in voer-/wateropname of productiedaling boven bepaalde grenzen; d) bij niet direct AI-verdachte verschijnselen (zoals eilegdaling, voeropnamedaling) onderzoek door middel van 'uitsluitingsswabs' (onderzoek op AI om deze uit te sluiten).

Diverse pluimveebedrijven zijn in de afgelopen 12 jaar meerdere malen besmet geraakt met laagpathogene AI-virussen (LPAI). LPAI-virus van $\mathrm{H} 5$ of $\mathrm{H} 7$ subtype kan muteren naar een hoogpathogene variant en een dergelijke LPAI-besmetting is daarom een serieus risico op een HPAIuitbraak. Bedrijven die meerdere malen met LPAI-virus besmet zijn geweest, zijn de zogenaamde 'hotspot'-bedrijven. Het betreft merendeels leghenbedrijven met vrije uitloop: ruim $80 \%$ van alle jaarlijkse LPAI virusintroducties op pluimveebedrijven betreft uitloop-legbedrijven (Bouwstra en Elbers, 2014). Gonzales et al. (2013) lieten zien dat uitloop-legbedrijven, kalkoenbedrijven, en eendenbedrijven (vlees en opfok/vermeerdering) een duidelijk hogere kans op introductie van LPAIvirussen hadden (periode 2007-2010) in vergelijking met legbedrijven die de dieren binnen houden. Er zijn geen aanwijzingen dat deze kans voor een directe introductie van HPAI-virus anders is.

Vleeskuikens leven maar kort, waardoor de kans op mutatie naar een hoogpathogene variant na introductie van laagpathogeen AI virus vanwege onder andere de incubatietijd relatief kleiner is.

\section{Kennis en ontwikkelingen}

Er is recent veel kennis verzameld over AI. De EFSA (2008) heeft een wetenschappelijke opinie uitgebracht over o.a. het risico van introductie van aviaire influenza op pluimveebedrijven. Het Nederlandse FES-AI consortium (2012) heeft de resultaten van haar onderzoeksprogramma beschreven in het rapport Vogelgriep Ontrafeld. Van der Goot et al. (2015) hebben een case-control studie uitgevoerd naar risicofactoren voor introductie van LPAI op legpluimveebedrijven met uitloop. Velkers et al. (2015) hebben een epidemiologische analyse gemaakt van de uitbraken van HPAI op pluimveebedrijven in de $2^{\mathrm{e}}$ helft van 2014. Daarbij zijn onder andere de risicofactoren voor insleep op de betrokken pluimveebedrijven in kaart gebracht. 
De omvangrijke HPAI-epidemie in 2015 in de USA vormt een andere relevante informatiebron voor risicoanalyse en aanpak. Ondanks dat de pluimveesector in de betrokken gebieden in de USA soms anders is gestructureerd dan in Nederland, zoals bijvoorbeeld ten aanzien van contactstructuren, kunnen ook daar mogelijk leerpunten voor de Nederlandse pluimveesector uit worden gehaald. De HPAI-epidemie in Frankrijk (eind 2015 - heden) heeft een heel ander karakter dan de Nederlandse, omdat het gaat om een gebied met veel eenden- en ganzenhouderijen, veelal in uitloopsystemen. Bij deze uitbraak, waarbij drie verschillende HPAI-virustypen werden gevonden, waren

ziekteverschijnselen en sterfte onder de geïnfecteerde eenden en ganzen beperkt, zoals mocht worden verwacht bij deze pluimveesoorten. De infectie werd daardoor pas opgemerkt toen ook bedrijven met leghennen werden getroffen (die na een infectie met HPAI-virus hoge sterfte laten zien) en al veel eenden- en ganzenbedrijven waren geïnfecteerd. De Franse epidemie laten wij vooralsnog buiten beschouwing, omdat er op dit moment weinig informatie over beschikbaar is.

Uitlooplegbedrijven hebben een bijna 8x grotere kans om LPAI virus in te slepen in vergelijking met legbedrijven die de dieren binnen houden (Bouwstra en Elbers, 2014). Direct en indirect contact via wilde (water)vogels, die een reservoir zijn voor LPAI-virussen, lijkt daarin een belangrijke factor. Om het risico op insleep te verkleinen ligt de focus in het huidige onderzoek met name op de wijze waarop wilde (water)vogels virus zouden kunnen overbrengen naar gehouden pluimvee en de mogelijkheden om wilde (water)vogels te weren uit de uitlopen. In de periode 2015-2016 werd onderzoek uitgevoerd op vijf hotspot-LPAI bedrijven met leghennen en vrije uitloop. Ieder kwartaal vond er een 24uurstelling plaats van vogels in en rond de uitloop om een indruk te krijgen van de vogelsoorten die zich ophouden bij en in uitlopen. Dit onderzoek zal meer inzicht geven in risicofactoren op pluimveebedrijven met uitloop en mogelijke preventieve maatregelen.

Implementatie en rigoureuze toepassing van hygiënemaatregelen kan een belangrijke rol spelen bij het buiten de deur houden van AI virus. Naar aanleiding van de uitbraken eind 2014 hebben het pluimveebedrijfsleven en GD een hygiënescan opgezet, waarmee pluimveehouders hun prestatie op uiteenlopende hygiënemaatregelen kunnen scoren: het is een digitale tool waarmee het hygiënemanagement voor alle typen pluimveebedrijven wordt gemonitord [bron:

https://www.avined.nl/nieuws/hygienescan-operationeel].

Vroegdetectie van LPAI-virusinfecties op pluimveebedrijven is een belangrijke factor in de preventie van mutatie van LPAI- naar HPAI-virus binnen de pluimveesector. LPAI-virus van H5 of H7 subtype kan mogelijk al binnen enkele weken muteren in HPAI-virus, en dat is reden voor de verplichte melding van een verhoogde uitval en/of consultatie van een dierenarts bij dalingen in voer- en wateropname en eiproductie. Elbers en Van der Spek (2015) hebben productiegegevens van legpluimveebedrijven met een bevestigde introductie van LPAI-virus geanalyseerd en zijn nagegaan hoe snel ná dalingen in voer- en wateropname en eiproductie op het bedrijf monsters of gestorven kippen zijn ingestuurd of melding is gemaakt van een verdachte klinische situatie. Handelingsperspectief voor preventie van introductie van LPAI/HPAI-virus op pluimveebedrijven heeft enerzijds te maken met de beschikbaarheid van effectieve preventieve (hygiëne)maatregelen en technieken voor vroege detectie, anderzijds of de gewenste management- en operationele maatregelen worden opgevolgd en nageleefd in de praktijk. Sociaaleconomische en gedragspsychologische ${ }^{1}$ aspecten (o.a. mindset) bepalen of gewenste maatregelen navolging vinden. Steeds vaker komt naar voren dat 'de mens geen homo economicus is, en slechts beperkt rationeel en beperkt wilskrachtig' (Tiemeijer, Thomas \& Prast 2009; WRR 2014). Gedragswetenschappelijk onderzoek laat zien dat mensen niet altijd weloverwogen en goed geïnformeerd kiezen, vaak een voorkeur hebben voor voortzetten van een bestaande situatie (de status quo), niet alleen worden gedreven door financieel eigenbelang, een korte termijn kleine winst prevaleren boven een grotere winst op lange termijn, gevoelig zijn voor wat anderen doen en onbewust worden beïnvloed door omgevingsfactoren (WRR, 2014). Om een strikte preventie van introductie van LPAI/HPAI-virus op pluimveebedrijven te kunnen bevorderen dient er, naast aandacht voor technische maatregelen, nadrukkelijk aandacht te worden besteed aan mechanismen die op effectieve wijze het gedrag van

\footnotetext{
${ }^{1}$ http://www.wrr.nl/publicaties/samenvattingen/samenvatting-de-menselijke-beslisser/3-gedragseconomie-in-de-praktijk/ Kennis van cognitief-psychologische mechanismen kan helpen om gedrag, persoonlijke financiële planning en prosociaal gedrag te verklaren. Dat mensen gevoelig zijn voor de wijze waarop keuzes aan hen worden voorgelegd betekent dat hun keuzes te beïnvloeden zijn (WRR-verkenning 'De menselijke beslisser', 2009).
} 
pluimveehouders kunnen veranderen, zodat risicobeperkende maatregelen door hen worden geadopteerd.

\section{Opdracht}

De pluimveesector heeft binnen de PPS Poultry4Food aan Wageningen Livestock Research (WLR) gevraagd om handelingsperspectief voor preventie van AI-insleep op legpluimveebedrijven aan te geven op basis van bestaande kennis en kennis die uit lopend onderzoek komt. Met als uiteindelijk doel om implementatie en naleving van effectieve managementmaatregelen (hygiëne, vroegdetectie) te bevorderen om het risico op uitbraken van LPAI/HPAI te verkleinen. Deze opdracht is door WLR in afstemming met experts op het gebied van sociale wetenschappen (Wageningen Economic Research) en veterinaire experts (Wageningen BioVeterinary Research) uitgewerkt. Dit rapport geeft een weergave van de bevindingen.

De volgende vragen staan centraal:

- Zijn de risicofactoren bekend en zijn er voldoende preventieve maatregelen voorhanden om het risico op insleep van AI op bedrijven met leghennen te minimaliseren?

- Waar zit op dit moment handelingsperspectief voor de sector en pluimveehouders?

- Waar zitten belangrijke hiaten in de kennis over risicofactoren en preventieve maatregelen?

- Hoe kan vroege detectie van besmetting met LPAI-virus in de praktijk worden ondersteund?

- Hoe kan implementatie en naleving van effectieve preventieve maatregelen door leghennenhouders worden bevorderd en ondersteund?

\section{Leeswijzer}

Dit rapport bestaat uit twee delen.

Deel I geeft aan waar op dit moment handelingsperspectief zit voor pluimveehouders en andere betrokkenen bij de sector om het risico op insleep van AI te minimaliseren. Het bevat in hoofdstuk 2 concrete adviezen voor pluimveehouders: waar zitten goede mogelijkheden in de preventie van insleep van AI op maat voor het bedrijf. In hoofdstuk 3 zijn relevante kennishiaten kort samengevat en aanbevelingen gedaan voor aanpak ervan.

In deel II is bestaande kennis over risicofactoren, oplossingsrichtingen en vroegdetectie (hoofdstuk 4), en kennis over bevorderen van gewenst (preventief) gedrag en mogelijk instrumentarium (hoofdstuk 5) samengevat. Deel II vormt mede de basis voor het aangegeven handelingsperspectief in deel I.

De opdracht is uitgevoerd met de focus op bedrijven met legpluimvee, omdat daar de belangrijkste risico's voor insleep van AI-virus en eventuele mutatie van LPAI- in HPAI-virus liggen. Voor alle typen pluimveebedrijven geldt evenwel dat hygiënemaatregelen belangrijk zijn, niet alleen voor AIpreventie, maar ook om andere ongewenste kiemen buiten de deur te houden. Daar waar 'leghennen' staat bij bijvoorbeeld de risicozonering in hoofdstuk 2, kan veelal ook 'pluimvee' worden gelezen. 


\section{DEEL I HANDELINGSPERSPECTIEF}




\section{Handelingsperspectief voor pluimveebedrijven}

Voor legbedrijven zonder vrije uitloop zijn al veel effectieve preventieve maatregelen bekend, waarmee het risico op insleep van HPAI en/of LPAI-virus kan worden beperkt (zie hoofdstuk 4). De uitdaging daarbij is enerzijds om te zorgen voor een vertaalslag naar maatregelen 'op maat' voor het bedrijf en anderzijds voor het stimuleren van een consequente naleving van preventief handelen bij het dagelijkse werk. Een consequente naleving van preventief handelen is van groot belang in tijden van verhoogd risico, maar evenzeer van belang in 'normale' tijden (denk aan het risico op insleep van LPAI-virus, dat zou kunnen muteren in HPAI-virus). Daarbij heeft naleving van een goede biosecurity ook positieve gevolgen voor het buiten de deur houden van andere pluimveeziekten. Wat voor legbedrijven zonder uitloop geldt, geldt ook voor andere 'dichte' bedrijven, zoals vleeskuiken-, vermeerderings-, kalkoen- en eendenbedrijven. (Ook) voor die bedrijven is een strikte hygiëne om veel meer redenen van belang dan alleen het risico op AI-insleep.

Voor legbedrijven met vrije uitloop zijn diverse maatregelen geopperd op het gebied van inrichting, afgrenzing en beheer van de uitloop, waarmee watervogels als belangrijke infectiebron voor LPAI zouden kunnen worden geweerd of afgestoten. De vrije uitloop kan een belangrijke 'open entree' zijn voor introductie van AI-virus. Vroege detectie van een besmetting is op deze bedrijven extra van belang en geeft extra uitdagingen (zie 2.3).

\subsection{Vertaalslag biosecurity 'op maat' voor bedrijf: waar zit handelingsperspectief}

\subsubsection{Indeling in risicozones}

De belangrijkste besmettingsroute voor insleep van AI-virus is direct contact met (uitwerpselen van) besmette vogels, pluimvee of andere uitscheiders van AI-virus of indirect contact met besmette uitwerpselen die via mechanische vectoren vanuit de omgeving de stal zijn binnengebracht (Koch en Elbers, 2006). Mechanische vectoren, voorwerpen die aan de buitenkant zijn verontreinigd met mest en/of andere mogelijke besmette deeltjes, kunnen het virus als een soort 'vehikel' naar het pluimvee brengen. Denk daarbij aan ratten en muizen, insecten, huisdieren, mensen (via schoeisel, kleding, handen), materialen, transportmiddelen, aerosolen in inkomende lucht. De uitdaging is om direct en indirect contact tussen uitwerpselen van potentiele uitscheiders van AI-virus en de leghennen in de stal zo lastig mogelijk te maken. Door de biosecurity te richten op het weren van 'vreemde' uitwerpselen-mest uit de verblijfsruimten van de hennen wordt niet alleen het risico op insleep van AI verkleind, maar ook het risico op insleep van andere schadelijke kiemen geminimaliseerd (voor handelingsmogelijkheden in de uitlopen, zie 2.1.4).

Iedere bedrijfslocatie kan wat mogelijke besmetting met 'vreemde' uitwerpselen-mest betreft in verschillende zones worden verdeeld (naar het 3-zone-biosecuritymodel FAO):

- $\quad$ een schone, sterk afgeschermde en beperkt toegankelijke groene zone met de verblijfsruimten van de leghennen,

- $\quad$ een oranje-gele zone met erfverharding en bedrijfsfunctionele gebieden, waar preventieve maatregelen kunnen worden genomen om de verontreiniging met 'vreemde' mest te verminderen tot een gemiddeld of laag besmettingsrisico,

- $\quad$ een rode zone van externe gebieden (onverharde wegen, sloten, weilanden, natuur e.d.) met een hoog besmettingsrisico, en waar de pluimveehouder beperkt handelingsperspectief voor verlaging van het risico heeft.

Door aan iedere zone en op de overgangen tussen de zones weloverwogen (en praktisch goed uitvoerbare) hygiënemaatregelen te hangen, kan het risico op insleep naar de dierverblijven worden verminderd of geminimaliseerd. 
Wij geven pluimveehouders daarvoor het volgende stappenplan in overweging:

Stap 1: Maak de drie risicozones (groen, oranje, rood) voor het eigen bedrijf inzichtelijk. Bij voorkeur samen met de dierenarts, bijvoorbeeld tijdens de jaarlijkse bespreking van het bedrijfsgezondheidsplan en de hygiënescan. Een Google-Earth foto van de bedrijfslocatie kan behulpzaam zijn als ondergrond voor het inkleuren van de zones. Voordeel is dat de verschillende risicozones voor pluimveehouder op deze wijze helder worden gevisualiseerd.

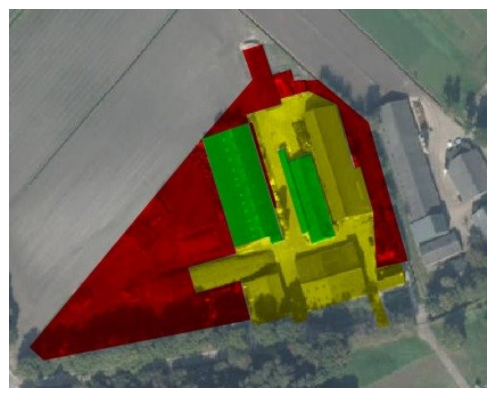

Figuur 1 Voorbeeld risicozonering op een vleeskuikenbedrijf

Stap 2 Geef binnen dit overzicht in grote lijnen aan:

- de plaats van voersilo's, mestopslag, kadaveropslag, hygiënesluis, voorlokalen, eventueel andere veestallen;

- $\quad$ hoe de externe loop- en transportlijnen in de bestaande situatie lopen (bezoekers; transport kuikens, hennen, eieren, voer, mest; transportmiddelen van andere activiteiten op bedrijf (loonwerkers, trekkers voor een melkveetak e.d.);

- hoe de interne looplijnen voor het leghennengedeelte lopen (looplijnen dierverzorgers, dierenarts/andere erfbetreders, afvoer dode dieren, ruwvoertransport, ...).

Stap 3 Analyseer indien van toepassing waar externe loop- en transportlijnen zo kunnen worden omgelegd dat ze loop- en transportlijnen van interne activiteiten niet meer kruisen en/of niet meer dicht langs de (luchtinlaten van) pluimveestallen lopen.

Stap 4 Richt het bedrijfsterrein waar nodig opnieuw in: bepaal de groene, gele, oranje en rode zones. $\underline{\text { Stap } 5}$ Stel vast welke hygiënische maatregelen men wil verbinden aan de verschillende zones en aan de overgangen tussen de zones (zie ook hierna).

\subsection{Optimale inrichting bedrijfsterrein (bij nieuwbouw, verbouw)}

In de optimale situatie, bijvoorbeeld te realiseren bij nieuwvestiging of nieuwbouw, kan de inrichting van het bedrijfsterrein er uit zien zoals is geschetst in de Maatlat Duurzame Veehouderij (MDV) voor pluimveestallen (leghennen). Interne looplijnen en extern verkeer zijn hierbij strikt van elkaar gescheiden.

- Het schone gedeelte is volledig omheind.

- De vulpunten van silo's zijn geplaatst aan de vuile weg.

- De kadaverplaats en de opslag van mest zijn gelokaliseerd op de scheiding tussen de schone en de vuile weg.

- De hygiënesluis voor personeel en bedrijfsbezoekers is eveneens op de scheiding tussen schone en vuile weg.

- $\quad$ Iedere stal heeft een eigen voorlokaal met omkleedruimte. 


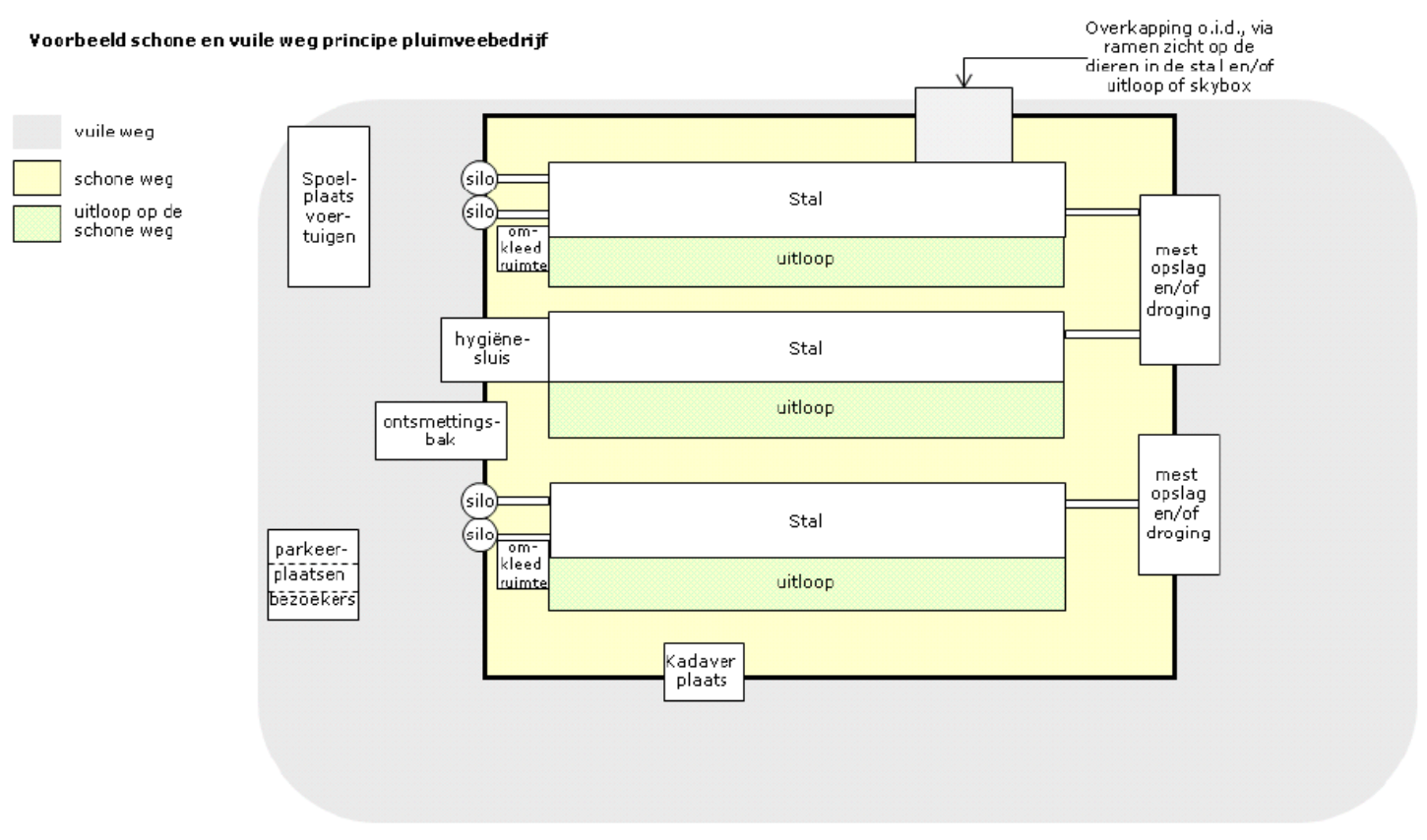

Figuur 2 Scheiding schone en vuile weg bij nieuwvestiging/nieuwbouw van een pluimveebedrijf (bron: Maatlat Duurzame Veehouderij Certificatieschema Pluimveehouderij 2016)

Kanttekening bij de MDV-schets: De schets lijkt meer te zijn toegespitst op vleeskuikenbedrijven dan op bedrijven met leghennen. De uitlopen zijn veel te klein en een eiersorteer en -afleverruimte zijn bijvoorbeeld niet ingetekend. Het principe van de scheiding tussen schone en vuile weg wordt wel duidelijk, en daar gaat het MDV in deze schets om. In het 3-zonemodel vallen de stallen met uitlopen onder de groene zone. De gele zone is in de MDV-schets ook geel van kleur, hier vindt alleen intern transport plaats. Het grijze gebied in de MDV-schets zou in het 3-zonemodel een oranje kleur krijgen (de erfverharding met externe transportlijnen). En alles daarbuiten zou onder de rode zone vallen.

\subsection{Handelingsperspectief in bestaande situaties}

Op bestaande pluimveelocaties komen vaak veel minder optimale situaties voor dan in 2.1.2 geschetst, zeker op leghennenbedrijven met ook andere veehouderijtakken zoals melkvee. Toch is vaak meer mogelijk dan men in eerste instantie denkt om het 'schone' gedeelte met de pluimveestallen te beschermen tegen insleep van AI-virus en andere kiemen vanuit het 'vuile' gedeelte. Het denken in risicozones op het bedrijf kan hierbij ondersteunen.

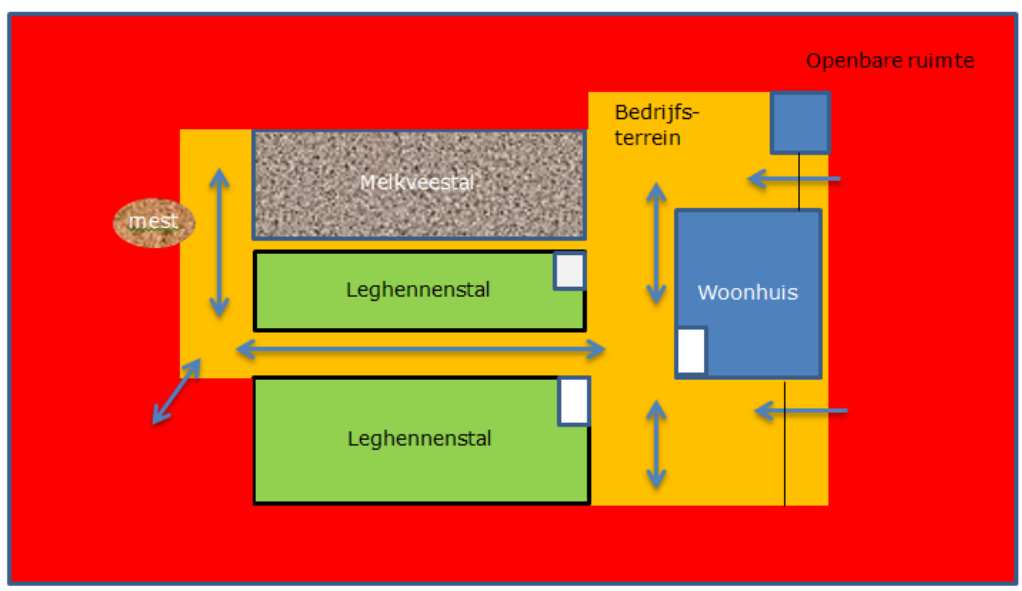

Figuur 3 Voorbeeld onderverdeling van een bedrijfslocatie met leghennen en melkvee in risicozones 


\section{Verdediging van de groene zone: prioriteit nr. 1!}

De groene zone omvat de stallen met de verblijfsruimten van het pluimvee. De voorlokalen vallen hier binnen. De begrenzing van de groene zone is de allerbelangrijkste scheidslijn tussen het pluimvee en mogelijke bronnen van HPAI en LPAI. Om AI (en gelijktijdig een aantal andere ziekteverwekkers) buiten de deur te houden verdient het 'verdedigen' van die groene scheidslijn de eerste prioriteit op elk pluimveebedrijf!

Dit zijn de belangrijke onderdelen van de verdediging:

$\rightarrow \quad$ Veel handelingsperspectief voor de pluimveehouder zit in de inrichting en het gebruik van het voorlokaal. De pluimveehouder moet er vanuit gaan dat de 'buitenwereld', alles buiten de stalmuren, in principe besmet kan zijn met AI-virus (en andere kiemen die hij liever buiten houdt). Met een goed ingericht voorlokaal en consequente toepassing van het hygiëneprotocol kan insleep van besmetting via schoeisel, kleding, handen van personen in de dagelijkse praktijk worden voorkomen.

Een optimaal ingericht voorlokaal kan er uit zien zoals in fig. 4.

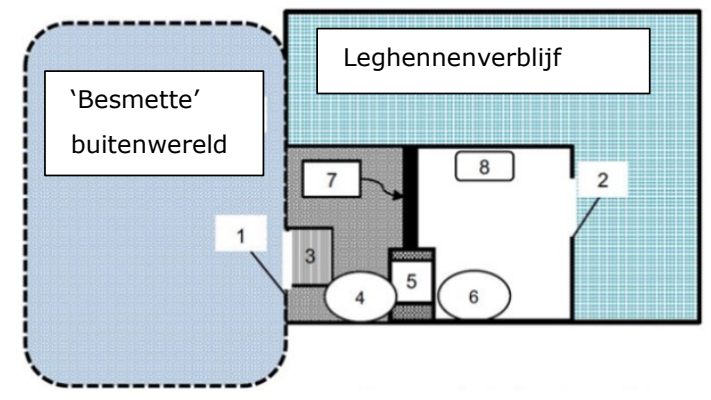

Figuur 4 Voorbeeld twee-zone voorlokaal (naar Deens model)

$1=$ toegangsdeur. $2=$ deur naar leghennenverblijf. $3=$ voetbad
met werkzame desinfectans. $4=$ opslag voor vuile
buitenlaarzen en overalls. $5=$ bankje of stoel om op te zitten
bij het wisselen van schoeisel. $6=$ opslag voor schone
stallaarzen en staleigen overalls. $7=$ scheidingslijn tussen het
vuile en schone gedeelte om overheen te stappen. $8=$
handenwasvoorziening en logboek.

Bij nieuwbouw is een dergelijk ingericht voorlokaal eenvoudig te realiseren. Maar ook in bestaande voorlokalen is met een slimme inrichting en eenvoudige extra voorzieningen vaak al meer mogelijk dan men denkt.

Belangrijk is ook dat het voorlokaal alleen wordt betreden door personen die zich al eerder hebben omgekleed in bedrijfseigen kleding en schoeisel. Dat vormt een extra beveiliging voor het geval er in het voorlokaal toch kruising plaatsvindt tussen het vuile en schone gedeelte. In Denemarken wordt mede daarom ook wel gewerkt met voorlokalen met drie zones: vuil, grijs en schoon (zie fig. 5). Op legbedrijven zonder hygiënesluis kan die extra zonering in het voorlokaal een goede optie zijn (maar elders op het bedrijf omkleden in bedrijfseigen kleding en schoeisel is dan misschien wel eenvoudiger te realiseren).

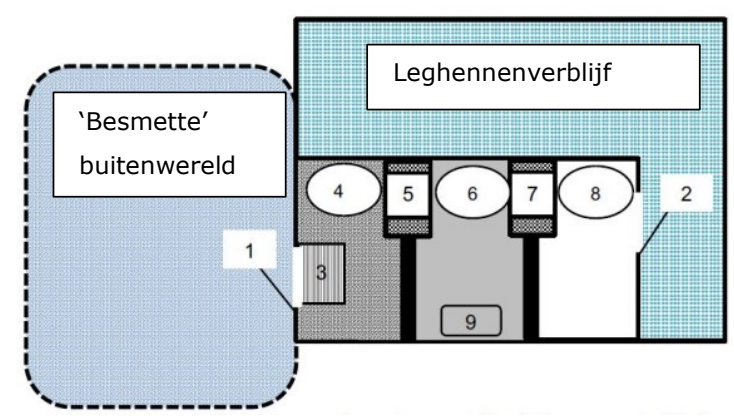

Figuur 5 Voorbeeld drie-zone voorlokaal (naar Deens model)

1 =toegangsdeur. $2=$ deur naar leghennenverblijf. $3=$ voetbad met werkzame desinfectans. $4=$ opslag voor vuile buitenlaarzen en overalls. $5=$ bankje of stoel om op te zitten bij het wisselen van schoeisel en scheiding tussen vuile en grijze deel. $6=$ opslag voor 'grijze' plastic overschoentjes. $7=$ bank of stoel voor wisselen 'grijze' overschoentjes voor schone stallaarzen en scheiding tussen grijs en schoon gedeelte. $8=$ opslag voor schone stallaarzen en staleigen overalls. $9=$ handenwasvoorziening en logboek. 
Soms zijn voorlokalen in bestaande oudere stallen zo klein, dat de belangrijke scheiding tussen het vuile en schone gedeelte lastig is te realiseren. In die gevallen kan een eenvoudige aanbouw met bijvoorbeeld wanden van gaas rondom de toegangsdeur een goedkope oplossing bieden (zie foto).

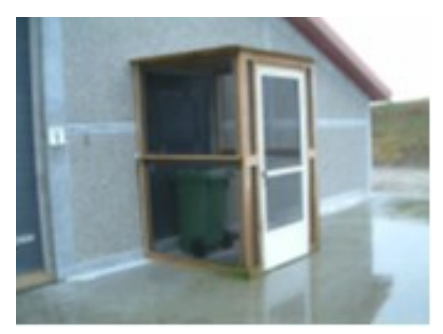

$\rightarrow \quad$ Het voorlokaal moet zo goed mogelijk vrij worden gehouden van ratten, muizen en insecten. Daarbij is het belangrijk dat de dagelijks gebruikte toegangsdeuren zo kort mogelijk openstaan. Het aanbrengen van (snel sluitende) drangers op de deuren is een goede mogelijkheid. Er zijn verschillende andere methoden om het binnenkomen van insecten door deuren tegen te gaan, zoals het plaatsen van tochtgordijnen (verticaal hangende pvc-flappen) of luchtgordijnen (verticale of gecombineerd verticale-horizontale luchtstroom; uit onderzoek blijkt een luchtstroom van gemiddeld $4 \mathrm{~m} / \mathrm{s}$ al $95-100 \%$ van de vliegen buiten te houden). Afgesloten afvalbakken en een goede vliegen- en ongediertebestrijding in het voorlokaal zijn eveneens van belang.

$\rightarrow$ Er zit ook handelingsperspectief in het weren van vogels, ongedierte en insecten uit de verblijfsruimten van de leghennen, en waar relevant bestrijden om het contactrisico met de kippen te minimaliseren. Toch is dit niet altijd eenvoudig, zeker niet in oudere stallen. Twee verdedigingslinies zijn van belang. 1) De directe omgeving rondom de stal zo onaantrekkelijk mogelijk maken voor ongedierte en insecten. Het aantal broed- en rustplaatsen voor vliegen en schuilplaatsen voor ongedierte kan worden beperkt door opslag en struiken die direct tegen de stal staan te verwijderen, te zorgen voor een goede waterafvoer rondom de stal en het gras rond de stal kort te houden. Of nog beter: te zorgen voor een strook verharding direct rondom de stallen; het maaien van gras kan immers aanwezige uitwerpselen doen opwervelen en die kunnen met de ventilatielucht de stal in worden getrokken. Bovendien is gras aantrekkelijk voor wilde vogels. 2) Gaten en kieren in stalmuren en deuren zo goed mogelijk afsluiten, dat geldt ook voor doorgangen van eierbanden en mesttransportbanden.

In de PPS 'Campylobacter de baas' (2015-2018) worden bij vleeskuikenstallen de zijwanden met de ventilatieopeningen bij wijze van experiment volledig met gaas afgedekt om vliegen te weren. Onderzocht wordt of op deze wijze besmettingen met Campylobacter zijn terug te dringen of te voorkomen (de huisvlieg wordt als potentieel belangrijke bron van besmetting met Campylobacter gezien).

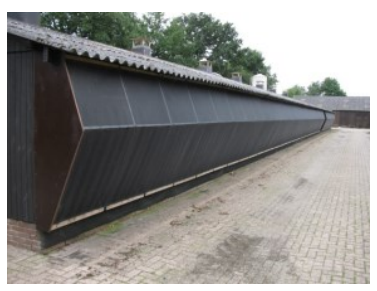

Foto (H. Ellen): gaas over zijwand bij een vleeskuikenbedrijf dat deelneemt aan het Campylobacter-onderzoek. Hiermee worden vliegen, maar ook ratten en muizen geweerd. Kosten en baten worden in het onderzoek meegenomen.

In het rapport 'Preventieve maatregelen tegen huisvliegen in vleeskuikenstallen' (Mul et al., 2016) zijn diverse mogelijkheden beschreven om huisvliegen te weren uit de stal en de omgeving van de stal voor vliegen zo onaantrekkelijk mogelijk te maken.

(http://library.wur.nl/WebQuery/wurpubs/fulltext/378258)

$\rightarrow$ Aandachtspunt: monitoring van het aantal vliegen in de stal. Pluimveehouders geven vaak aan weinig vliegen in de stal te zien. Dit is ook niet verwonderlijk, want aanwezige vliegen worden vermoedelijk snel weggevangen door de kippen. Door op relevante plekken zoals bij ventilatieopeningen, boven voerhoppers, bij grote deuren en dergelijke regelmatig plak/lijmvallen op te hangen, krijgt de pluimveehouder een indruk van het aantal vliegen dat toch nog in de dierverblijven weet te komen (pluimveemest heeft een grote aantrekkingskracht op 
vliegen) en meer inzicht in nut en noodzaak van eventueel extra vliegenwering en bestrijding in de 'groene' zone.

$\rightarrow \quad$ Na bovenstaande punten is er nog een belangrijk aandachtspunt voor verdediging van de groene zone tegen insleep van AI-virus (en andere kiemen). Materialen, instrumenten en hulpmiddelen die van buiten het voorlokaal en/of de dierverblijven worden ingebracht, dienen schoon te zijn en zo nodig vooraf te worden gereinigd en ontsmet, zodat er geen mestdeeltjes of mogelijke besmettingsbronnen meer aan kunnen kleven. Zo veel mogelijk staleigen materialen gebruiken: bezems, emmers, vanghaken en dergelijke.

$\rightarrow \quad$ Een laatste punt van aandacht in de verdediging van de 'groene zone' vormt de wijze van opslag en in de stal brengen van strooisel en ruwvoer (bv. luzerne) en strooigraan (CCM, stro). Opslag in afgesloten ruimten en/of goed afgedekt voorkomt in elk geval dat het strooisel en/of ruwvoer in die fase verontreinigd kan raken met uitwerpselen van wilde vogels en ongedierte. Bij aankoop van strooisel en ruwvoer is het verstandig om garanties te vragen over de wijze van opslag door de verkoper.

De eerste verdedigingslinie is nu ingericht. Het hangt mede af van de bedrijfssituatie wat er verder gedaan kan worden om de mate van besmetting van het bedrijfsterrein te verlagen.

\section{Managen van het bedrijfsterrein: de oranje zone}

Ieder professioneel pluimveebedrijf beschikt in meer of mindere mate over erfverharding, waar zich doorgaans ook de bedrijfsfunctionele gebieden bevinden. Niet altijd is binnen het bedrijfsterrein een gele zone te realiseren waarbinnen alleen intern verkeer gericht op het pluimveedeel plaatsvindt (zie bij gele zone). Toch is ook de oranje zone, het bedrijfsterrein waar noodgedwongen extern verkeer over heen gaat, een gebied waar pluimveehouders handelingsperspectief hebben:

$\rightarrow \quad$ Ten eerste door het bedrijfsterrein fysiek en consequent af te sluiten met een ketting of hek van de buitenwereld om onverwachte bezoekers buiten het bedrijfsterrein te houden en duidelijk aan te geven waar ze zich kunnen melden.

$\rightarrow \quad$ Idealiter bevinden eierautomaten of -verkooppunten zich aan de buitenkant van het bedrijfsterrein, zodat de gemêleerde en soms onbekende groep burgers die eieren komt kopen (waar zijn ze geweest, welke hobbydieren hebben ze thuis e.d.?) in principe niet op het bedrijfsterrein hoeft te komen. Temeer daar omkleden/bedrijfseigen schoeisel aantrekken bij deze groep in de regel geen optie is.

$\rightarrow \quad$ Er bevindt zich een omkleedruimte bij de ingang van het bedrijfsterrein. Bijvoorbeeld in de vorm van een container met een toegangsdeur aan de vuile kant en een deur aan de schone kant. Hierin kunnen dierverzorgers en bezoekers zich omkleden in bedrijfseigen kleding en schoeisel voordat ze het bedrijfsterrein betreden. Belangrijk om bedrijfseigen kleding en schoeisel voor het pluimveegedeelte gescheiden te houden van kleding en schoeisel waarmee bijvoorbeeld ook koeienstallen worden betreden.

$\rightarrow \quad$ Mogelijk besmette vogel- en andere uitwerpselen kunnen op verschillende manieren op de erfverharding terecht komen: via aanwezige of overvliegende (water)vogels, via honden en katten, via ongedierte, via aflopend regenwater van daken, via schoeisel van dierverzorgers en bezoekers, via wielen/ wielkasten van externe transportwagens, via eigen trekkers, kruiwagens e.d. Door de erfverharding regelmatig te reinigen en eventueel te ontsmetten kan de verontreiniging met vreemde mest worden beperkt. Het is verstandig om goten aan het dak te hebben, zodat aflopend regenwater dat mogelijk is verontreinigd met uitwerpselen van vogels niet zo op het erf loopt. Indien er veel overlast is van wilde vogels op de daken, kan ook worden overwogen om vogelwering op het dak aan te brengen (zie hiervoor gespecialiseerde bedrijven).

$\rightarrow \quad$ Voer- en mesttransportwagens zijn uitgerust met een R\&O-installatie om wielen en wielkasten te reinigen en ontsmetten. In tijden van uitbraken of verhoogd risico wordt deze R\&O consequent uitgevoerd. In bedrijfssituaties waarin voer- en mesttransportwagens noodgedwongen dicht in de buurt van de pluimveestallen moeten komen, is het verstandig dat de pluimveehouder deze handeling ook in 'normale tijden' vraagt van de betreffende transporteurs. 
$\rightarrow$ Indien de bedrijfssituatie het toelaat, dienen externe transportlijnen (voer-/mesttransport, trekkers voor melkveetak e.d.) zo mogelijk niet op korte afstand langs de pluimveestal(len) te lopen (minimaal $10 \mathrm{~m}$ ). Hiermee wordt voorkomen dat wervelende deeltjes afkomstig van deze transportmiddelen de stal in worden gezogen. In bestaande situaties is dit niet altijd uitvoerbaar.

$\rightarrow \quad$ De aantrekkelijkheid van het erf voor ongedierte en vliegen kan worden verminderd door het afdekken van eventueel aanwezige mesthopen (ook van andere diersoorten dan pluimvee), voeropslag en kuilen. Nog beter is het om te zorgen dat de mest van iedere ronde volledig van het erf is afgevoerd.

$\rightarrow \quad$ Het verlies van exsudaat (uittredend vocht) tijdens het verplaatsen van dode kippen kan worden tegengegaan door ze in emmers te vervoeren. De directe omgeving van de kadaverton dient schoon te zijn om geen vliegen en ongedierte aan te trekken.

\section{Gele zone: extra bufferzone rondom de pluimveestallen!}

In bepaalde bedrijfssituaties is het mogelijk om de interne loop- en transportlijnen voor de pluimveetak fysiek af te scheiden van de rest van het bedrijfsterrein waar ook externe transportlijnen lopen. In 2.1.2 is al een ideaalplaatje geschetst (MDV). Ook in minder ideale situaties is het vaak mogelijk om direct rondom een stal of de stallen een duidelijk afgebakende bufferzone aan te leggen waarbinnen geen kruising is met externe transportlijnen en het risico op verontreiniging met en introductie van 'vreemde' uitwerpselen/mest extra laag wordt gehouden: een gele zone.

$\rightarrow \quad$ Belangrijk is dat een gele zone slim wordt gekozen: de extra bufferzone rondom de stallen moet daadwerkelijk iets toevoegen aan preventie van insleep, de gekozen hygiënemaatregelen moeten 'op maat' zijn voor het bedrijf en praktisch haalbaar in de dagelijkse werkzaamheden.

$\rightarrow \quad$ Vaak kunnen eenvoudige maatregelen zoals een beperkte herindeling van het bedrijfsterrein en slim gekozen afscheidingen (mobiele paaltjes met kettingen) al een wezenlijk verschil maken.

$\rightarrow \quad$ Op bedrijven met meerdere veehouderijtakken kan het inrichten van een gele zone, de bufferzone rondom de pluimveestallen met alleen interne pluimveetransportlijnen, lastig zijn. In het eerder gegeven voorbeeld zou de ondernemer kunnen besluiten tot het aanleggen van een verharde weg achter de melkveestal langs, zodat extern transport en intern transport voor de melkveetak niet meer tussen de leghennenstallen door hoeft te rijden (fig. 6). Het pluimveegedeelte met de interne transportlijnen kan dan geheel worden afgescheiden van het melkveegedeelte. Dit is natuurlijk een relatief ingrijpende maatregel, die om een goede ondernemersafweging vraagt.

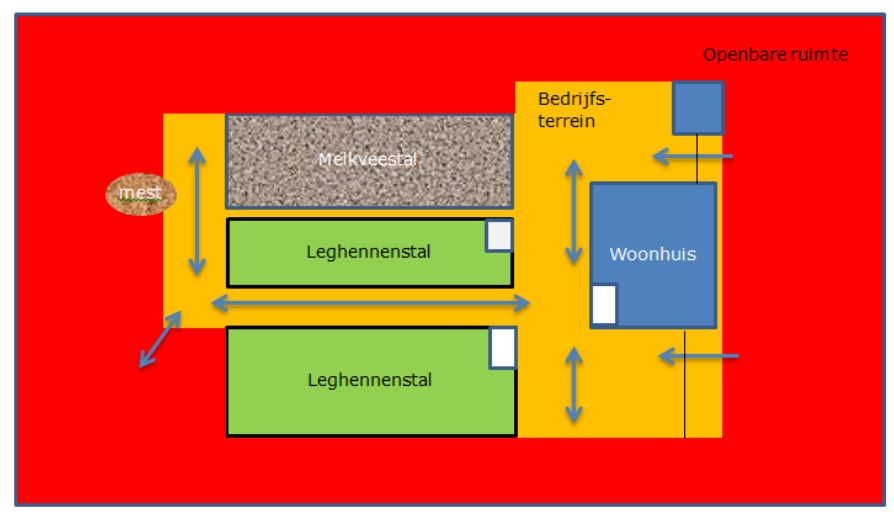

Figuur 6 Bedrijf met leghennen en melkvee

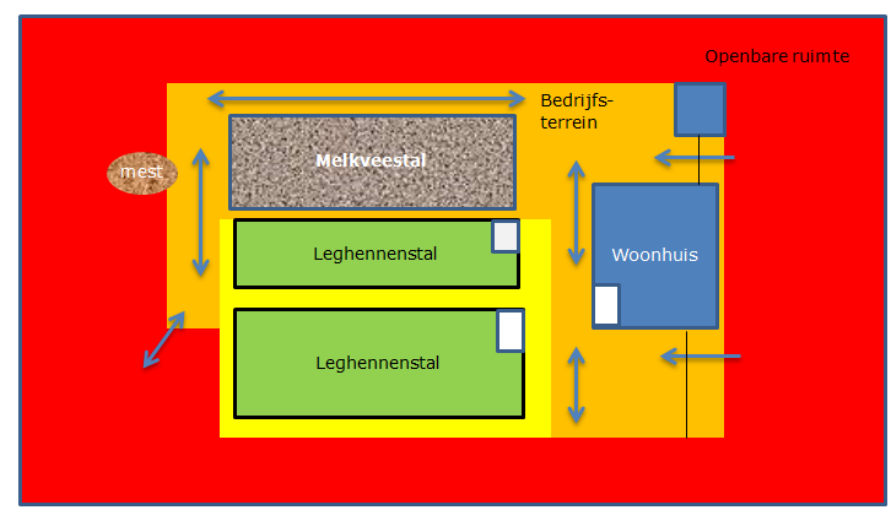

$\rightarrow$ Indeling in risicozones: bestaande situatie 
$\rightarrow \quad$ Idealiter zijn binnen de gele zone de pluimveestallen en interne looplijnen fysiek afgescheiden van de rest van het terrein, wordt de gele zone extra schoon gehouden (frequent reinigen en ontsmetten), hebben huisdieren er geen toegang en vindt er een effectieve ongedierte- en insectenbestrijding plaats. Voor toegang van bezoekers tot de gele zone kunnen extra hygiëneprotocollen worden ingezet (wie mag er komen; alleen toegang in bedrijfseigen kleding en schoeisel en dergelijke). Soms is het mogelijk om door het slim verlengen van vulpijpen voor voersilo's externe voertransportwagens op grotere afstand van de pluimveestal, buiten de gele zone, te houden.

\section{Rode zone: beperkt handelingsperspectief}

De rode zone omvat de externe gebieden met onverharde wegen, sloten en andere waterpartijen, weilanden, akkerbouwgrond, buurbedrijven, natuur en dergelijke. In deze zone heeft de pluimveehouder slechts beperkt handelingsperspectief:

$\rightarrow \quad$ Bij de HPAI-uitbraken in de USA bleek actieve grondbewerking nabij kalkoenbedrijven in de 14 dagen voorafgaand aan de uitbraak een risicofactor te zijn. Transmissie via de lucht zou een mogelijke reden kunnen zijn. In 'normale tijden' is het handelingsperspectief voor de pluimveehouder op dit punt naar verwachting gering. Pluimveehouders met tevens akkerbouwgrond kunnen bij grondbewerkingen eventueel rekening houden met ongunstige windrichtingen. [In tijden van vogeltrek of in perioden van uitbraken kan er (regionaal) mogelijk van hogerhand enige regulatie worden gezet op het uitvoeren van intensieve grondbewerkingen in de buurt van pluimveehouderijen, maar dat valt buiten de invloed van individuele pluimveehouders].

$\rightarrow \quad$ Geen direct handelingsperspectief bij eigen ruwvoerwinning zoals CCM en luzerne (extra vogelwering?).

$\rightarrow \quad$ Indien het bedrijfsterrein grenst aan open wateren of aan gebieden waar veel watervogels foerageren, is extra alertheid op zijn plaats. Het is belangrijk om te zorgen voor een goede afscheiding van het bedrijfsterrein, en in het bijzonder indien er sprake is van vrije onoverdekte uitlopen, met de sloten, open wateren of de foerageergebieden van ganzen, eenden en andere watervogels. In paragraaf 4.1.4 gaan we in op het handelingsperspectief binnen vrije uitlopen.

$\rightarrow \quad$ Het zou zeker voordelen kunnen hebben indien buurbedrijven gezamenlijk afspraken maken over biosecuritymaatregelen die ook voor de anderen van belang kunnen zijn (zoals over eventuele grondbewerkingen, locatie en wijze van mestopslag, ongediertebestrijding). De haalbaarheid daarvan zal per locatie verschillen.

\subsubsection{Specifiek handelingsperspectief in de vrije uitloop}

De vrije uitloop kan een belangrijke open entree zijn voor introductie van AI-virus. Er leven nog vele vragen over optimale inrichting en beheer van de vrije uitloop uit oogpunt van zowel dierenwelzijn als diergezondheid en preventie van insleep van AI-virus. Toch hebben bedrijven met vrije uitloop ook nu al wel enig handelingsperspectief voor AI-preventie, met name gericht op voorkomen van contact tussen het pluimvee en (uitwerpselen van) wilde watervogels in de uitloop:

$\rightarrow \quad$ Handelingsperspectief begint met het zorgen voor een goede afscheiding tussen de uitloop en aangrenzende sloten, open wateren of foerageergebieden van ganzen, eenden en andere watervogels. Als er watervogels vanuit de omgeving (het bedrijfsterrein en/of) de vrije uitloop op kunnen lopen, dient het terrein langs sloot of betreffend weiland te worden begrensd met gaas. Binnen IKB Ei is een afrastering met gaas van ten minste 1 meter hoogte verplicht rond waterpartijen die zich binnen of aan de randen van de uitloop bevinden. Afhankelijk van de lengte van de benodigde begrenzing zal hier een meer of minder hoge kostenpost aan verbonden zijn.

$\rightarrow \quad$ Er zijn alternatieve opties denkbaar, zoals het inzetten van een (getrainde) hond in of rondom de uitloop en/of op het bedrijfsterrein. Honden kunnen worden getraind in het verjagen van andere dieren (waaronder 'vreemde' vogels maar ook bv. vossen) die de vrije uitloop of het 
bedrijfsterrein betreden of willen betreden. In Australië wordt dit op sommige pluimveebedrijven met vrije uitloop toegepast, in Nederland zijn er vooralsnog geen ervaringen mee (Van der Goot et al., 2015). Het risico op overdracht van kiemen door contact (direct of indirect) tussen hond en pluimvee zal dan in elk geval een aandachtspunt moeten zijn.

$\rightarrow$ De officiële omvang van de vrije uitloop is in de praktijk vaak ruimer dan het gedeelte dat daadwerkelijk door de kippen wordt benut. Dit kan een reden zijn dat inrichtingselementen in de vrije uitloop niet als significante risico- of beschermende factoren voor insleep van LPAI naar voren zijn gekomen (Van der Goot et al, 2015). Een kip is een bosdier; watervogels zoals ganzen en eenden hebben andere voorkeuren, ganzen foerageren graag in weilanden. Praktijkprojecten hebben laten zien dat er diverse mogelijkheden zijn om de vrije uitloop met beplanting aantrekkelijk te maken voor de kippen, en daarmee gelijker tijd minder aantrekkelijk voor watervogels (zie 2.2.1). Daaronder vallen uitlopen in fruitboomgaarden, notenbomen, groepjes kerstbomen in de uitloop, wilgenplantages met de wilgen in stroken, velden met maïs of tarwe of aanplant van miscanthus (olifantsgras), mits geen hele uitlopen ermee worden bedekt (Skal/KAT). Ook zonnepanelen in de uitloop worden door Skal/KAT toegestaan. Belangrijk is om voor ogen te houden dat tijdelijk beschermen van jonge planten tegen kippenvraat (afschermen) van KAT alleen mag als de kippen in totaal nog steeds $4 \mathrm{~m} 2$ vrije uitloop per dier houden. Skal gaat daar in overleg soms iets soepeler mee om (Bestman, 2014).

$\rightarrow \quad$ Apart schoeisel en handen wassen indien van uitloop naar uitloop/bedrijfsterrein en vice versa? Via IKB Ei is het verplicht om bij het betreden van het bedrijfsterrein vanuit de vrije uitloop gebruik te maken van apart schoeisel. Door pluimveehouders worden vraagtekens gezet bij nut en noodzaak van deze maatregel. Vanuit het perspectief van AI-insleep lijkt deze maatregel minder relevant. Een stal bestaat bijvoorbeeld uit 6 gescheiden compartimenten (inclusief gescheiden overdekte uitloop) met elk 6000 kippen. Deze kippen komen in de praktijk doorgaans samen in de vrije uitloop, zodat eventuele besmettingen via de vrije uitloop tussen compartimenten kunnen worden uitgewisseld. Indien er meerdere stallen op het bedrijf zijn die daadwerkelijk als epidemiologische eenheid fungeren, bijvoorbeeld compartimenten/stallen met verschillende leeftijden of verschillende merken kippen, is het verstandig om via fysieke belemmeringen te voorkomen dat dierverzorgers direct van de ene uitloop in de andere uitloop kunnen stappen. Bijvoorbeeld via hoog hekwerk. Indien na elkaar twee dergelijke uitlopen moeten worden betreden, is wisseling van schoeisel (en kleding) en het wassen van de handen zeker een zinvolle hygiënische tussenstap. Maar, dat gaat dan vooral om het voorkómen van versleep van bedrijfsgebonden ziekten tussen gescheiden epidemiologische eenheden, en niet zozeer over preventie van introductie in en versleep van AI over het bedrijf. Zodra AI-introductie wordt vastgesteld, komt het hele bedrijf met alle stallen onder het daarbij passende regime: insleep is insleep. Kortom: apart schoeisel en handen wassen tussen uitlopen onderling en met het bedrijfsterrein zijn in bepaalde bedrijfssituaties zinvolle hygiënische maatregelen, maar niet zozeer om insleep van AI te voorkomen.

\subsubsection{Meer belang bij goede biosecurity}

Het consequent uitvoeren van effectieve maatregelen in de groene en oranje-gele zone op het bedrijf is voor alle bedrijven van belang. Bedrijven met uitloop in waterrijke gebieden en/of op kleigrond lopen meer risico op introductie van AI-virus vanwege de (mogelijke) aanwezigheid van watervogels: het rode gebied is voor ene bedrijf (nog) risicovoller dan voor het andere. Bedrijven in AIrisicogebieden dienen daarom nog alerter te zijn op een goede preventie.

Voor alle bedrijven heeft een goede AI-preventie echter een belangrijk bijkomend voordeel. Met preventieve maatregelen om AI buiten de deur te houden, zal ook het risico op insleep van andere schadelijke kiemen/organismen zoals Salmonella, infectieuze bronchitis (IB), bloedluis, darmparasieten, Gumboro en Campylobacter kunnen worden geminimaliseerd. Ook de productiviteit en het dierenwelzijn zullen daarom gebaat zijn bij een goede AI-preventie. 


\subsection{Vroegdetectie: handelingsperspectief}

Een vroege detectie van insleep van LPAI-virus op legbedrijven is belangrijk om de kans op eventuele mutatie naar een hoogpathogene variant te voorkomen (Koch and Elbers, 2006). Uit analyse blijkt dat de wettelijk voorgeschreven perioden voor melden van afwijkende productiekengetallen op bedrijven die met LPAI besmet zijn geraakt, niet altijd zijn nageleefd (Elbers en Van der Spek, 2015). De langste perioden zijn waargenomen tussen een verhoging in uitval en het moment waarop daadwerkelijk kadavers voor sectie naar GD zijn gestuurd. Om pluimveehouders gemotiveerd te krijgen of te houden voor vroeg melden van verhoogde uitval is het van belang om de kans op 'loos alarm' zo klein mogelijk te maken:

$\rightarrow \quad$ Bepaalde redenen voor verhoogde uitval zijn goed zichtbaar in de stal: bijvoorbeeld het ineens op een hoop lopen (troepen) bij (bepaalde merken) kippen, met veel uitval als gevolg. Of verhoogde uitval als gevolg van uitbraak van een bekende bedrijfsgebonden ziekte. Het is belangrijk dat de pluimveehouder in overleg met zijn dierenarts duidelijke andere oorzaken dan een mogelijke besmetting met AI-virus op voorhand kan uitfilteren.

$\rightarrow \quad$ Ook hebben factoren als wel/geen behandelde snavels en wel/geen buitenuitloop invloed op schommelingen in de uitval. De motivatie kan naar verwachting ook worden vergroot indien de meldingsgrenzen (de range waarbinnen schommelingen in uitval als 'normaal' kunnen worden beschouwd) worden gerelateerd aan het type bedrijfssysteem. WBVR onderzoekt in 2016 in opdracht van EZ nieuwe meldingsgrenzen voor uitval, waarbij de hiervoor genoemde factoren relevant kunnen zijn om in de analyse te betrekken indien die informatie voorhanden is.

\subsection{Handelingsperspectief voor ondersteunen preventief gedrag pluimveehouders}

Eén van de onderzoeksvragen was hoe naleving van preventieve maatregelen voor reductie van het risico op insleep van HPAI/LPAI-virus op legpluimveebedrijven kan worden bevorderd.

Gedrag heeft te maken met technische, sociaaleconomische en gedragspsychologische factoren. Een gewenste gedragsverandering op pluimveebedrijven gericht op preventie van AI-insleep zal niet spontaan tot stand komen. Het bevorderen van gewenst (preventief) gedrag door pluimveehouders, ook in 'normale tijden', vraagt om een samenhangende inzet van verschillende instrumenten. Het RESET-model (zie § 5.3) kan hierbij als handvat worden gebruikt. Het wenkend perspectief is een optimale RESET-set, waarbij regelgeving, educatie, sociale druk, economische prikkels en ondersteunende tools in onderlinge samenhang worden ingezet.

We kunnen concluderen dat de RESET-set op dit moment onvoldoende is gevuld, aangezien het gewenste preventieve handelen met betrekking tot insleep van AI-virus niet sectorbreed is geïmplementeerd door pluimveehouders. We gaan in op handelingsperspectief voor sector en overheid om hier verandering in te brengen.

\section{Regelgeving ( $R$ )}

* Regelgeving in relatie met preventie van AI-virus insleep is deels gevuld via het private IKB-

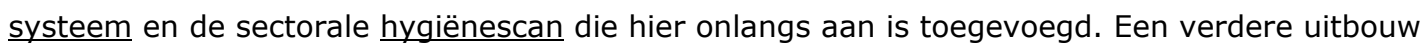
van de hygiënescan en benutting in sectorbrede benchmarking en als aanleiding voor verplichte verbeteracties zal de komende jaren aan de orde zijn. De maatregelen in de scan dienen dan wel eenduidig te interpreteren en controleerbaar te zijn. Een aantal maatregelen zal in dat geval naar verwachting moeten afvallen. Tevens kan worden overwogen om de hoogte van de wegingsfactor die is verbonden aan bepaalde maatregelen in de hygiënescan afhankelijk te maken van de geospatiale (wel-niet waterrijk gebied/kleigrond e.d.) en bedrijfsspecifieke kenmerken (wel/geen uitloop; situering van stallen en bedrijfsterrein ten opzichte van de buitenwereld e.d.) van een bedrijf.

* De hygiënescan is een generieke tool. In de toekomst zou ook een meer bedrijfsspecifieke tool aan een IKB-systeem kunnen worden verbonden, als stimulans voor het identificeren van de 
bedrijfsspecifieke risicozones en het verbinden van preventie/hygiënische maatregelen aan risicozones en de overgangen ertussen. Een dergelijke bedrijfsspecifieke tool zou ook kunnen worden gekoppeld aan de jaarlijkse verplichte evaluatie van het bedrijfsgezondheidsplan door dierenarts met pluimveehouder. Zie verder bij Tools $(T)$.

\section{Educatie (E)}

* Educatie lijkt tot nu toe vooral te zijn gericht op studiegroepen (daar wordt een deel van pluimveehouders mee bereikt), generieke informatie over hygiënemaatregelen en algemene artikelen in vakbladen. De verschillen in persoonlijkheidskenmerken van individuen maken duidelijk dat overtuigingsstrategieën en educatie zorgvuldig moeten zijn afgestemd op de kenmerken van de verschillende doelgroepen en individuele verschillen daarbinnen (zie 5.2). Zorg dat er een breed palet aan producten voor informatieoverdracht en educatie beschikbaar is, zodanig dat uiteenlopende typen pluimveehouders er op de ene of de andere wijze door worden getriggerd en er het 'hunne' uit kunnen halen: via studiegroepen; via bijeenkomsten van eierhandel, voerleveranciers en/of primaire sector; via eenvoudige visuele voorlichtingsproducten; via kennisproducten met meer diepgaande achtergrondinformatie. Vraag pluimveehouders die persoonlijk te maken hebben gehad met AI om te vertellen over de impact en het belang van preventie (tijdens bijeenkomsten en/of interviews in vakbladen). Mensen zijn gevoelig voor wat andere mensen doen: benadruk daarom hoeveel collega-pluimveehouders het gewenste gedrag al uitvoeren in plaats van de nadruk te leggen op het risicovolle gedrag.

* Vertel pluimveehouders zonder vrije uitloop waarom hygiënische maatregelen van groot belang zijn voor preventie van AI-virusinsleep (de uitbraken van HPAI in 2014 onderstrepen dit; tevens vindt circa $20 \%$ van de LPAI-uitbraken plaats op bedrijven zonder uitloop). Vertel pluimveehouders met vrije uitloop waarom het belangrijk is om, evenals op bedrijven zonder uitloop, ook de andere insleeproutes zo goed mogelijk te blokkeren.

* Voorlichting en educatie is niet alleen belangrijk richting leghennenhouders, maar ook richting dierenartsen, stallenbouwers, bouwbureaus voor optimale inrichting van bouwblokken bij nieuwen verbouw, beoordelaars van vergunningen en andere. Bij bedrijfsontwikkeling kan het voordelen hebben om de dierenarts in een vroeg stadium mee te laten kijken naar een optimale inrichting van bouwblok/bedrijfsterrein voor wat betreft preventie van insleep van kiemen (waaronder AI) en verspreiding tussen stallen.

\section{Sociale druk (S)}

Sociale druk is een belangrijke prikkel voor gedragsverandering en het volhouden van bepaald gedrag. De dierenarts en andere erfbetreders, de directe omgeving en collega-pluimveehouders spelen daarbij een wezenlijke rol (als kennisbron en als boodschappers van de 'sociale norm' ten aanzien van preventie). Dierenartsen komen doorgaans slechts in een lage frequentie op legbedrijven. De samenwerking tussen dierenarts en andere erfbetreders zoals de voervoorlichter en ketencoach met de pluimveehouder lijkt in de legpluimveehouderij ook nog maar mondjesmaat van de grond te zijn gekomen. Dit bemoeilijkt sociale druk via die weg.

* De jaarlijkse evaluatie van het bedrijfsgezondheidsplan door de dierenarts met de pluimveehouder is een belangrijk moment om risicofactoren en verbeterpunten in de biosecurity goed te evalueren en waar gewenst een verbeterplan in te zetten, en daarmee sociale druk te zetten. De bedrijfsspecifieke analysetool met risicozonering kan hierbij een belangrijke ondersteunende rol vervullen.

* Transparant maken voor de buitenwereld van de score op de hygiënescan, bijvoorbeeld 3 jaar na introductie ervan, kan ook een middel zijn om sociale druk te zetten.

\section{Economische prikkels (E)}

Economische prikkels voor pluimveehouders voor het uitvoeren van preventieve maatregelen ter preventie van AI-insleep (en ook in algemene zin) zijn op dit moment niet of nauwelijks voorhanden. De enige economische prikkel voor een sectorbrede aanpak van een stringente preventie loopt op dit moment via de hoogte van de sectorbijdrage aan het Diergezondheidsfonds. 
* Maak eventuele economische voordelen van een versterkte preventie door minder bedrijfsgebonden ziekten of betere productieresultaten zichtbaar. Analyse van preventieplan, productieresultaten, kosten-batenanalyse en ervaringen van voorbeeldbedrijven zouden in de vakpers kunnen worden beschreven.

* Ga na of de motivatie voor melding van verhoogde uitval ten behoeve van een vroege detectie van LPAI kan worden bevorderd door bij een negatieve uitslag op AI de ingestuurde monsters tevens te testen op andere mogelijke oorzaken voor de verhoogde uitval en terug te koppelen naar de pluimveehouder.

* Daarnaast valt te denken aan specifieke subsidieregelingen om investeringen in hygiënische voorzieningen te bevorderen.

* Ook is het van belang om systemen daar waar mogelijk aan elkaar te koppelen: bijvoorbeeld de uitkomst van de hygiënescan, en uitvoering van een bedrijfsspecifieke risicotool met zonering, niet alleen verbinden aan IKB maar ook aan bijvoorbeeld de Maatlat Duurzame Veehouderij, die van belang is bij voorgenomen bedrijfsontwikkeling, zodat er punten mee kunnen worden verdiend.

\section{Ondersteunende tools ( $\mathrm{T}$ )}

Ondersteunende tools moeten het de pluimveehouder makkelijker maken om bepaald gewenst gedrag uit te voeren.

* Voorbeelden zijn bouwtekeningen van goed ontworpen voorlokalen, met praktische voorzieningen en duidelijke instructiebordjes; formats voor het helder aangeven van looplijnen op het bedrijf; per stal een bepaalde kleur laarzen en overalls; checklisten met risicofactoren en mogelijke verbetermaatregelen; instructiekaarten. Het kunnen ook tools zijn die het gedrag van de pluimveehouder onbewust in een bepaalde richting sturen.

* De sectorale hygiënescan is een generieke tool, met een lijst van maatregelen waarop een bedrijf punten kan scoren. Het instrument is niet bedoeld en niet geschikt als analysetool voor specifieke bedrijfssituaties. Een mogelijke bedrijfsspecifieke tool is eerder aangegeven: identificeren van de rood-oranje/geel-groen risicozones per bedrijf en daaraan koppelen van zinvolle en praktisch haalbare hygiënemaatregelen, binnen zones en op de overgangen tussen zones. Het verdient overweging deze tool verder te ontwikkelen in de praktijk (met pluimveehouders en dierenartsen).

Concreet wordt in overweging gegeven om de volgende tools op korte termijn uit te werken:

- De bedrijfsspecifieke tool verder uitwerken: een hulpmiddel/instructie voor pluimveehouder/dierenarts om de risicozones inclusief loop-/transportlijnen van het pluimveebedrijf in kaart te brengen (groen-oranje/geel-rood; gebruik van Google-Earth) en een checklist en plan van aanpak om maatregelen binnen de onderscheiden zones en op de overgangen tussen de zones vast te leggen;

- $\quad$ Een waaier of digitaal product met inspirerende voorbeelden van ongewenste situaties met betrekking tot biosecurity en eenvoudige praktische aanpassingen met de gewenste voorbeelden. Daarbij veel gebruik maken van visualisaties (foto/filmmateriaal);

- Het boek Kipsignalen uit te breiden, zoals voor de melkveehouderij is gedaan, met een Checkboek met de belangrijkste checklisten, scorekaarten en instructiekaarten die de legpluimveehouder ondersteunen bij het dagelijks managen van het legpluimveebedrijf. Biosecurity hier expliciet onderdeel van laten uitmaken. Het Koesignalen Checkboek bevat een bundeling van de 54 belangrijkste checklists, scorekaarten en instructiekaarten die de melkveehouder ondersteunen bij het dagelijks managen van het melkveebedrijf.

In hoofdstuk 3 zijn belangrijke kennishiaten samengevat en aanbevelingen gedaan voor aanpak ervan. 


\section{Enkele kennishiaten en aanbevelingen voor vervolgonderzoek}

In hoofdstuk 2 is bestaand handelingsperspectief voor preventie van insleep van AI-virus door pluimveehouders en ondersteuning daarvan op sectorniveau geschetst. Daarbij zijn diverse aanbevelingen gegeven voor uit te werken acties. In dit hoofdstuk noemen we tot slot enkele relevante hiaten in de kennis, en geven we aanbevelingen voor aanpak ervan.

Kennishiaten met betrekking tot preventie van insleep van AI-virus bevinden zich, vanuit het perspectief van de pluimveehouder, ten minste op vier lijnen:

Kennishiaat 1: Begrenzing, inrichting en management van de vrije uitloop, met een integrale aanpak gericht op optimale benutting van de uitloop door de hennen, het weren van watervogels, en een goede praktische haalbaarheid en gunstige kosten-batenverhouding voor de pluimveehouder, en met waardering door burger/consument. De rol van vogelsoorten die een brugfunctie in transmissie van AI-virus kunnen vervullen (tussen wilde watervogels en het commercieel gehouden pluimvee) en hoe deze eventueel kunnen worden geweerd uit de uitloop is eveneens een punt van aandacht. Aandacht voor preventie van insleep in risicotijden en in 'normale tijden'.

Aanbeveling: Uitvoeren van een Reflexief Interactief Ontwerptraject (RIO-onderzoek) op uitloopbedrijven, zoals eerder uitgevoerd in project Houden van Hennen (Rondeel e.d.), voortbouwend op resultaten van praktijknetwerken zoals Bomen voor Buitenkippen en andere.

Kennishiaat 2: Gedragspsychologische en sociaaleconomische karakteristieken van groepen van pluimveehouders en de wijze waarop de gewenste gedragsveranderingen het beste kunnen worden ondersteund.

Aanbeveling: Onderzoek uitvoeren naar tools waarmee gewoontegedrag kan worden doorbroken en gewenst gedrag inzake preventie van AI-virus insleep bewust of onbewust kan worden gestimuleerd.

Kennishiaat 3: Managementondersteuning voor vroegdetectie van introductie van LPAI-virus, waarbij de frequentie van 'loos alarm' wordt geminimaliseerd.

Aanbeveling: Een door Woudenberg et al. (2015) voorgesteld computersysteem voor vroegdetectie van introductie van LPAI-virus aan de hand van afwijkingen in eiproductie kan bijdragen aan het voorkomen van het aantal keren 'loos alarm'. Het is de bedoeling om daaraan in de toekomst nog een beslissingsondersteunend model voor NVWA-dierenartsen te koppelen, waarin door koppeling van o.a. klinische verschijnselen op dier- en koppelniveau het aantal 'loze' meldingen mogelijk verder kan worden beperkt. Het is verstandig om een dergelijk model ook uit te werken voor koppeling aan managementsystemen van pluimveehouders.

Kennishiaat 4: Bedrijfsspecifieke risicotool voor pluimveebedrijven

Aanbeveling: In een praktijkpilot nagaan in hoeverre een bedrijfsspecifieke risicotool met indeling in risicozones (zie 2.3) toepasbaar en werkbaar te maken is op uiteenlopende typen (leg)pluimveebedrijven. Pilot met (leg)pluimveehouders, hun dierenarts/andere relevante erfbetreder(s) en onderzoeksteam (WUR/GD). Finetunen van de risicotool en toets op (ervaren) effectiviteit. Demonstratieproject naar andere pluimveebedrijven en brede uitrol naar sector. 


\section{DEEL II SAMENVATTING BESTAANDE KENNIS}




\section{$4 \quad$ Kennis over risicofactoren en preventieve maatregelen}

In dit hoofdstuk gaan we in op risicofactoren en op bekende technische en andere (preventieve) maatregelen die pluimveehouders kunnen nemen om het risico op introductie van LPAI/HPAI-virus op een pluimveebedrijf te beperken.

\subsection{Bestaande kennis HPAI-uitbraken}

\subsubsection{HPAI in Nederland}

In het voorjaar van 2003 en in het najaar van 2014 waren er uitbraken van hoogpathogene vogelgriep in Nederland. In 2003 betrof het een epidemie waarbij een introductie van H7N7 LPAI-virus werd gevolgd door mutatie naar een H7N7 HPAI-virus op het indexbedrijf en verdere verspreiding van het HPAI-virus naar andere pluimveebedrijven, en zijn er in totaal 255 besmette bedrijven, met name in de Gelderse Vallei, geruimd. Voor het grootste deel van de infecties in 2003 is niet duidelijk geworden welke transmissieroutes hebben gezorgd voor verspreiding van bedrijf naar bedrijf. In gebieden waar pluimveebedrijven dicht bij elkaar liggen kan overdracht via de lucht (m.n. via besmet stof) een rol hebben gespeeld (FES, 2012).

Eind 2014 zijn vijf pluimveebedrijven ( 3 bedrijven met leghennen, 1 bedrijf met vleeskuikenouderdieren en 1 bedrijf met vleeseenden) besmet geraakt met een H5N8 HPAI-virus (Bouwstra et al., 2015). Deze bedrijven bevonden zich in relatief pluimvee-arme gebieden en in waterrijke gebieden met gunstige omstandigheden voor verschillende soorten watervogels (Velkers et al., 2015). Het waren allemaal pluimveebedrijven zonder buitenuitloop. In de 10-km zones rondom de besmette bedrijven bevond zich slechts één pluimveebedrijf met (niet-overdekte) buitenuitloop. De beperkte pluimveedichtheid heeft er zeer waarschijnlijk aan bijgedragen dat het aantal besmette bedrijven beperkt is gebleven. Op zeker vier en waarschijnlijk vijf van de vijf bedrijven leek het een primaire uitbraak te betreffen, d.w.z. op alle bedrijven is afzonderlijk het virus geïntroduceerd en hebben de bedrijven elkaar niet onderling besmet (Bouwstra et al., 2015).

Ten aanzien van contacten, hygiëne en management op de HPAI-besmette bedrijven in 2014 concluderen Velkers et al. (2015) het volgende (letterlijk geciteerd):

- Er zijn geen contacten geïdentificeerd die wijzen op tussen-bedrijf transmissie van het H5N8 virus;

- Een duidelijke aanwijsbare gemeenschappelijke route voor insleep in de stal werd niet gevonden;

- Wel zijn diverse risicofactoren ontdekt die in wisselende mate voorkwamen bij de bedrijven:

- Veel wilde (water)vogels in de directe omgeving van de bedrijven;

- De bedrijven bevinden zich in waterrijke/vogelvriendelijke gebieden;

- Vlakbij de stallen bevinden zich sloten en/of rivieren, aantrekkelijk voor watervogels;

- Zangvogels (spreeuwen) en duiven in en rond het erf, aangetrokken door bomenrijen en begroeiing;

- Vogelmest op het erf, tegen de stal, soms zelfs lopend langs ventilatie-openingen;

- Veel ongedierte (muizen en ratten) in en rondom het bedrijf:

- Sloten; onafgedekte mestopslag; onverharde grond/begroeiing rondom de stal en rommel op het erf maken het aantrekkelijk voor ongedierte;

- Kieren, gaten en spleten in de stal; mestbanden; eierbanden bieden toegang aan ongedierte van buiten naar binnen in de stal;

- Mogelijkheden voor verslepen van virusdeeltjes over het erf en naar de stal:

- Ontsmettingsbakken, omkleden en wisselen van schoeisel niet altijd consequent toegepast;

- Honden en katten, die zowel in de weilanden komen als op het erf;

- Aan huis verkoop van eieren;

- Regenwater van daken van de stallen (incl. vogelmest) komt terecht op het erf; 
- Aanvoer van stro of andere producten van weilanden bij vleeseendenbedrijven (en soms ook bij leghennenbedrijven) / toegang wilde vogels of ongedierte tot opslag van stro;

- Maaien van gras bij de stal kan mestdelen opwervelen richting ventilatie-openingen van de stal;

- Ongediertebestrijding na ruiming wordt bemoeilijkt door aanwezigheid van mest en voer in de geruimde stal en voldoende fourageermogelijkheden in stallen in de buurt.

Aanbevelingen ten aanzien van hygiëne- en managementmaatregelen (letterlijk geciteerd). Om de kans op uitbraken te reduceren geven Velkers et al. (2015) de volgende aanbevelingen:

- Beperken aanwezigheid wilde vogels (inclusief spillover gastheren zoals zangvogels en duiven):

- Vermijden van aantrekkelijke plekken, zoals slootjes, bomenrijen en begroeiing vlakbij de stal, en in ieder geval het verharden van een stuk grond rondom de gehele stal;

- Beperken verslepen van virus naar en over het erf:

- Zorgen voor nette afvoer van regenwater van de daken van stallen (niet op het erf);

- Weren van ongedierte rondom de stal:

- Minder aantrekkelijk maken omgeving: sloten, begroeiing en onverharde delen rondom stal beperken, geen rommel op het erf, ontoegankelijk maken mestopslag voor ongedierte;

- $\quad$ Professionele bestrijding laten uitvoeren door een gecertificeerd bedrijf;

- Beperken contact van honden en katten met weilanden en (de omgeving van) de stal;

- Aan huis verkoop van eieren:

- Afschaffen of strikt aan de weg laten plaatsvinden;

- Bij verplaatsen eieren van stal naar verkooppunt schone weg/vuile weg principes hanteren;

- Registratie van mensen die de eieren kopen voor eventuele traceringsdoeleinden;

- Beperken insleep van virus in de stal:

- Beter afschermen van ventilatie-openingen van vogelmest;

- Opwervelen van virusdeeltjes uit wilde vogelmest door maaien van gras in de buurt van de stal beperken (verharden grond rondom de stal!);

- Eisen stellen / garanties vragen over de afwezigheid van / beperkte blootstelling van strooisel en ruwvoer aan mest van wilde vogels;

- Opgeslagen strooisel / ruwvoer vrijhouden van contact met wilde vogels en ongedierte;

- Beperken / minder aantrekkelijk maken van toegangsplekken voor ongedierte in de stal, zoals kieren en spleten, mestbanden en eierbanden: hierbij wordt geadviseerd een professioneel, gecertificeerd bedrijf in te schakelen.

\subsubsection{Recente uitbraken HPAI in de USA}

In de periode december 2014-juni 2015 waren er 219 gevallen van HPAI virus infecties in de USA (USDA, 2015; www.aphis.usda.gov/AI), verspreid over meerdere staten. Daarbij waren ruim 48 miljoen stuks pluimvee betrokken. Epidemiologisch onderzoek in relatie met genetische analyse van de virusisolaten op de betrokken bedrijven wijst uit dat er sprake is geweest van ten minste 40 primaire introducties van het virus. Hiervan zijn 25 primaire introducties direct aangepakt en is verdere verspreiding voorkomen. In 15 gevallen heeft het virus zich echter verder kunnen verspreiden naar een groot aantal andere pluimveebedrijven.

Case-control studie Iowa: kwantitatieve analyse

In een case-control studie (USDA, 2015) uitgevoerd medio 2015 met 28 met HPAI-virus besmette leghenbedrijven/stallen (geen onderscheid in primaire en secundaire besmettingen) en 31 controle leghenbedrijven/stallen (niet besmet) in de staat Iowa (USA) kwamen vanuit een multivariate-analyse een aantal risicofactoren naar voren die geassocieerd waren met infectie.

Bedrijven in een bestaand controlegebied van de HPAI-epidemie bleken een verhoogd risico te lopen. Op bedrijfsniveau bleek de kadaverophaaldienst, indien het transportmiddel in de nabijheid van stallen met pluimvee kwam, een significante risicofactor te zijn. Ook de vuilniswagen bleek een belangrijke risicofactor te zijn indien de route dicht langs pluimveestallen ging. Bezoekers laten omkleden in bedrijfskleding daarentegen was een belangrijke beschermende factor. Hygiënische maatregelen zoals 
handen wassen en beschermend schoeisel kwam er in de multivariate analyse niet als significant uit, volgens de onderzoekers omdat dergelijke factoren waarschijnlijk alle hetzelfde biosecurity-

gerelateerde gedrag meten. Bezoek in de voorgaande 14 dagen van een erfbetreder vanuit de keten, en in het bijzonder als deze persoon ook de stallen heeft betreden, was eveneens een significante risicofactor. Dit hoeft geen oorzakelijk verband te zijn: het bezoek kan volgens de onderzoekers bijvoorbeeld ook samenhangen met een specifiek verzoek door de pluimveehouder vanwege bijzondere omstandigheden op het bedrijf.

Daarnaast zijn drie andere variabelen genoemd, die niet in het multivariate-model konden worden opgenomen vanwege weinig gegevens, maar mogelijk relevant zijn: het delen van rekken en pallets tussen bedrijven als potentiele risicofactor, en handen wassen door werknemers en vliegenbeheersing als potentiele beschermende factoren.

Op stalniveau vond men drie variabelen die geassocieerd waren met infectie. Een verhard pad naar de toegang tot de stal dat was gereinigd en ontsmet was beschermend in vergelijking met onverharde paden of het ontbreken van reinigen of desinfecteren. Kadaveropslag binnen 30 yards (d.i. ca. 27 meter) van de stal was een significante risicofactor. Ventilatiesystemen met inkomende lucht via plafonds of dakranden waren beschermend (minder risico) ten opzichte van tunnel-, gordijn- of zijwandventilatie.

\section{Case-control studie Iowa: kwalitatieve analyse}

Tijdens de interviews voor de case-control studie in Iowa zijn ook open vragen aan de betrokken pluimveehouders gesteld (USDA, 2015). Hierbij zijn geïnterviewden gevraagd naar hun gedachten over de wijze waarop het virus zich heeft verspreid binnen hun regio, de invloed van bekend positieve bedrijven op de routing van transportwagens, het patroon van verspreiding van het virus binnen hun stallen (alleen besmette bedrijven), en een plattegrond van hun productielocatie met aan- en afvoerroutes, stallen, opslag van voer, mest, kadavers en dergelijke.

\section{HPAI-verspreiding binnen de eigen regio}

Veel pluimveehouders waren van mening dat het virus via de lucht was verspreid, en dat het in sommige gevallen was verspreid via de lucht na grondbewerkingen en/of irrigatie op nabijgelegen land.

In de staat Iowa komen veel zogenaamde veehouderij 'companies' voor, waarbij een company uit vier of meer veebedrijven/productielocaties bestaat. Een aantal pluimveehouders gaf aan dat 'company'managers of medewerkers soms op dezelfde dag meerdere of alle productielocaties van de company hebben bezocht, en zo het virus in potentie kunnen hebben verspreid. 'Companies' met 4 of meer locaties kwamen volgens de onderzoekers beduidend vaker voor onder de besmette bedrijven dan bij de groep niet-besmette bedrijven. Binnen een company is het collectief gebruik van voer- en andere transportmiddelen vanaf de hoofdlocatie naar de andere locaties volgens de onderzoekers een belangrijke potentiele verspreidingsroute. Men geeft aan dat ook andere gezamenlijk gebruikte materialen en uitwisseling van personeel niet als risicofactor kunnen worden genegeerd. De leghennenproductie in Iowa kent bovendien sterke onderlinge banden tussen 'companies' in gebruik van o.a. voer-, eier- en kadavertransportwagens en verwerkende bedrijven. De onderzoekers verwachtten ook daar een extra risico op verspreiding van virus tussen bedrijven, maar dat was niet af te leiden uit de uitgevoerde analyses.

\section{Verspreiding van het virus binnen de eerst geïnfecteerde stal}

Een aantal respondenten gaf aan dat binnen een geïnfecteerde stal doorgaans eerst de kippen nabij een ventilatie-inlaat ziek werden, en vervolgens de ziekte zich uitbreidde over de hele stal. Anderen gaven aan dat de ziekte begon aan de achterkant van de stal, aan de andere kant van waar de stalingang zich bevond. Ook hier werd een relatie gelegd met grote ventilatiesystemen die gericht waren op de achterkant van de stal.

\section{Andere bronnen USA}

Akkerbouwgronden kunnen besmet raken met besmette vogeluitwerpselen. Virus blijkt in een koude bodem te kunnen overleven. Een USA-internetbron (http://www.startribune.com/farmers-tillingnearby-fields-might-have-contributed-to-bird-flu-epidemic/366919751/) stelt naar aanleiding van 
onderzoek van de universiteit van Minnesota dat actief bewerken van de grond in de nabijheid van kalkoenenbedrijven in de 14 dagen voorafgaande aan een HPAI-uitbraak een risicofactor was. Men stelde dat transmissie via de lucht hier de reden van zou kunnen zijn. Bewerken van grond nabij stallen vond men alleen in het begin van de epidemie als een risicofactor. Volgens de onderzoekers suggereert dit dat het bewerken van grond geen rol heeft gespeeld in de secundaire verspreiding van het virus.

\section{USA maatregelen biosecurity AI}

De uitbraken met HPAI virus in de USA hebben aanleiding gegeven tot een versterkte aandacht voor biosecuritymaatregelen, met checklists en ondersteunende tools die breed toegankelijk zijn gemaakt op internet. Zoals een checklist waarmee pluimveehouders hun eigen situatie op het gebied van hygiëne- maatregelen in kaart kunnen brengen.

(http://www.uspoultry.org/animal_husbandry/assessment/checklist.cfm)

Samengevat ligt de focus van de adviezen op de volgende maatregelen:

1. Biosecurity officer;

Elk bedrijf of integratie van bedrijven zou een biosecurity officer moeten hebben die verantwoordelijk is voor de hygiëneplannen en -protocollen, naleving ervan en training van medewerkers op het bedrijf. Deze functionaris is een ervaren pluimveedierenarts of staat daarmee in contact. Deze functionaris moet ook zorgen voor training en instructie aan alle bedrijfsbezoekers, chauffeurs van transportwagens, servicepersoneel en anderen.

2. Scheidslijn;

Dit ziet men als een cruciaal onderdeel van versterkte biosecurity: de implementatie van een duidelijke scheidslijn voor elke stal (scheiding tussen pluimvee en potentiele bronnen van HPAI). En een plan dat aangeeft hoe de scheidslijn wordt gedefinieerd en 'verdedigd' tegen insleep van buitenaf.

3. De omtrek van een bufferzone;

In een bufferzone rondom de stal of stallen wordt besmetting met virus zoveel mogelijk voorkomen of gereduceerd (via hygiënemaatregelen en toegangsprotocollen).

4. Personeel; Maatregelen gericht op douchen en wisselen van kleding voor personen die de bufferzone betreden en/of over de scheidslijn heengaan.

5. Wilde vogels, knaagdieren en insecten;

Goede beheersingsprogramma voor het weren en bestrijden van de bovengenoemde soorten.

6. Goede reiniging en ontsmetting van materialen en gereedschappen. Geen gezamenlijk gebruik.

7. Een hygiënische kadaveropslag en afvoer, niet toegankelijk voor vogels of ongedierte.

8. Mest- en strooiselmanagement; bij afvoer blootstelling van gevoelig pluimvee er aan voorkomen, zowel op het bedrijf als elders.

9. Aanvoer van dieren van bedrijven met aantoonbare goede biosecurity en historie van HPAIvrij. Inclusief hygiënisch verantwoord transport van de dieren.

10. Drinkwatervoorziening. Afkomstig van diepe bronnen of van bronnen die behandeld zijn tegen levende virussen. Aparte, stringente protocollen indien oppervlaktewater als drinkwaterbron wordt gebruikt.

11. Voer en strooisel moeten zodanig zijn opgeslagen en worden toegepast dat ze niet besmet kunnen zijn of raken met AI.

Bij elk van de onderdelen is trainingsmateriaal gemaakt in de vorm van video's, handouts, protocollen en dergelijke, dat toegankelijk is op het internet (http://www.poultrybiosecurity.org/).

Met uitzondering van de biosecurity officer komen de USA-inzichten voor een belangrijk deel overeen met Nederlandse inzichten over relevante biosecurity-maatregelen (zie ook bij 4.4 Hygiënescan sector). 


\subsection{Bestaande kennis LPAI-uitbraken en inzichten uit lopend onderzoek (Nederland)}

\subsubsection{Case-control studie Nederland}

Legbedrijven met vrije uitloop hebben een 7.7 keer grotere kans op introductie van LPAI-virus dan legbedrijven zonder vrije uitloop (Gonzales et al., 2013). Van der Goot et al. (2015) hebben in een case-control studie in Nederland onderzoek gedaan naar risicofactoren voor introductie van laagpathogeen aviaire influenza (LPAI)virus op legpluimveebedrijven met vrije uitloop. Veertig bedrijven met een LPAI-virusintroductie in het verleden zijn vergeleken met 81 controlebedrijven zonder historie van een LPAI-virus besmetting. Uit dit onderzoek kwam naar voren dat legbedrijven waar ten minste één keer per week wilde eenden door de pluimveehouder in de uitloop werden gesignaleerd een 3.3 keer groter risico hebben op introductie van LPAI-virus dan op legbedrijven waar wilde eenden één keer of minder per maand in de uitloop werden gezien. Daarnaast bleken legbedrijven met vrije uitloop op kleigrond een 5.8 keer hoger risico op introductie van virus te hebben dan bedrijven met de uitloop op zandgrond of andere grondsoorten. Hier ligt waarschijnlijk een relatie met het feit dat kleigrond zich vooral in de nabijheid bevindt van de kust of rivieren, waar meer watervogels voorkomen dan in andere gebieden. De inrichting van de uitloop, zoals begroeiing en begrenzing, kwam niet naar voren als een risico-verlagende factor. Van de inrichting van de uitloop wordt echter wel een effect verwacht, gezien de mogelijke invloed ervan op de aanwezigheid van watervogels in de uitloop. Van der Goot et al. (2015) vonden voor introductie van LPAI-virus op legbedrijven met vrije uitloop ook geen significante risicofactoren die te maken hebben met bedrijfshygiëne of management. Men plaatst daarbij de kanttekening dat het aantal pluimveebedrijven in de studie relatief laag was (alleen de meest belangrijke factoren komen er dan uit) en dat alleen bedrijven zijn geselecteerd waarvan men aannam dat ze niet besmet waren geraakt door een ander bedrijf. Hierdoor hadden de onderzoekers vooraf al ingeschat dat een aantal factoren niet zou verschillen tussen case- en controlebedrijven.

Mogelijke preventieve maatregelen voor LPAI-insleep op legbedrijven met vrije uitloop hangen, naast de algemene biosecuritymaatregelen, naar verwachting samen met de inrichting van de uitloop en mogelijk ook met het uitloopmanagement. Eenden of andere wilde watervogels zouden door bepaalde inrichtingselementen aangetrokken of afgestoten kunnen worden. Als watervogels via de lucht de uitloop binnenkomen hebben ze ruimte nodig om te landen en op te stijgen, zoals plekken zonder opgaande begroeiing of bouwsels. Indien uitlopen grenzen aan waterpartijen kunnen watervogels vanaf het water de uitloop betreden als een adequate omheining ontbreekt. Uit onderzoek van het Louis Bolk Instituut (Bestman, 2015) komt naar voren dat een inrichting van de uitloop met veel bomen en struiken, zoals beplantingen met miscanthus (olifantsgras), fruitbomen of wilgenplantages, ervoor kan zorgen dat deze aantrekkelijker wordt voor de kippen en minder aantrekkelijk voor watervogels. Om AI-risicovogels te weren dient volgens Bestman (2015) zo min mogelijk grasland aanwezig te zijn. Met name zwanen en ganzen zouden op deze wijze geweerd kunnen worden. Eenden lijken op deze wijze minder gemakkelijk te weren.

Nader onderzoek door SOVON in de periode $2015-1^{\mathrm{e}}$ helft 2016 vond plaats op vijf hotspot-LPAI bedrijven met leghennen en vrije uitloop. Ieder kwartaal vond er een 24-uurstelling plaats van vogels in en rond de uitloop om een indruk te krijgen van de vogelsoorten die zich ophouden bij en in uitlopen. Dit onderzoek zal meer inzicht geven in risicofactoren op pluimveebedrijven met uitloop en mogelijke preventieve maatregelen.

\subsection{Vroegdetectie van LPAI}

Een insleep van HPAI-virus op een pluimveebedrijf wordt doorgaans snel gedetecteerd omdat het snel hoge sterfte in de stal veroorzaakt. Een LPAI-virus infectie vaststellen is veel lastiger: de klinische verschijnselen die LPAI-virus veroorzaakt in een koppel zijn vaak niet ernstig en kunnen ook worden veroorzaakt door diverse andere pluimveeziekten. Vroege detectie van introductie van LPAI-virus van subtype $\mathrm{H} 5$ of $\mathrm{H} 7$ is essentieel om mutatie naar een hoogpathogene variant te voorkomen. Het vroeg detecteren of er iets mis is in een koppel, veroorzaakt door een LPAI-virus of een andere aandoening, zou gebaseerd kunnen worden op afwijkingen in de dagelijkse productiegegevens zoals de 
voeropname, de wateropname, het aantal gelegde eieren en de mortaliteit in het koppel (Elbers et al., 2010).

Er vinden regelmatig introducties van LPAI-virus op pluimveebedrijven in Nederland plaats (Bouwstra en Elbers, 2014). In de periode 2010 t/m 2014 zijn er in totaal 27 LPAI- (H5 en H7) introducties geweest (d.i. gemiddeld ruim 5 keer per jaar een introductie van LPAI-virus van de subtypen $\mathrm{H} 5$ en $\mathrm{H} 7$ op pluimveebedrijven). LPAI virus van subtype $\mathrm{H} 5$ of $\mathrm{H} 7$ kan mogelijk al na enkele weken muteren in HPAI virus, en dat is reden voor de verplichte melding van een verhoogde uitval bij het meldpunt van de NVWA en/of consultatie van een dierenarts bij dalingen in voer- en wateropname en eiproductie. Art. 84 van de Regeling preventie, bestrijding en monitoring van besmettelijke dierziekten en zoönosen en TSE's (geldend vanaf 04-12-2015) verplicht legpluimveehouders om een verhoogde uitval aan een landelijk meldpunt voor dierziekten door te geven. Het gaat bij leghennen die ouder zijn dan 10 dagen om een verhoogde uitval op twee opeenvolgende dagen van 0,5\% of meer per koppel. Tevens dient een dierenarts te worden geconsulteerd indien een klinisch probleem zichtbaar is, indien er op twee opeenvolgende dagen een reductie in voer- of wateropname is van meer dan $5 \%$ per dag, en indien er op twee opeenvolgende dagen een reductie in eiproductie is van $5 \%$ of meer per dag. Een sterke aanwijzing voor een besmetting met HPAI virus (zichtbaar door exponentiele sterfte) moet direct worden gemeld; als er geen aanwijzingen zijn voor een aviaire influenza-infectie bij een voerof wateropnamedaling of eilegdaling doet de dierenarts binnen acht uur melding van het klinische probleem van de desbetreffende dieren of van de omstandigheden en van de naam- en adresgegevens van het bedrijf aan de Gezondheidsdienst voor Dieren.

Elbers en van der Spek (2015) hebben productiegegevens van legpluimveebedrijven met een bevestigde introductie van een LPAI-virus van subtype $\mathrm{H} 5$ of $\mathrm{H} 7$ geanalyseerd ( 6 bedrijven) en zijn nagegaan hoe snel ná dalingen in voer- en wateropname en eiproductie op het bedrijf monsters zijn ingestuurd. Op de geanalyseerde bedrijven zat een periode uiteenlopend van 0 tot 19 dagen tussen het optreden van een toename in de uitval van meer dan 0,5\% en het insturen van kadavers ter sectie. De perioden tussen het optreden van een reductie in voeropname en het insturen van kadavers voor sectie liepen op de geanalyseerde bedrijven uiteen van 1 tot 13 dagen. En tussen daling in eiproductie en insturen van kadavers voor sectie van 1 tot 8 dagen.
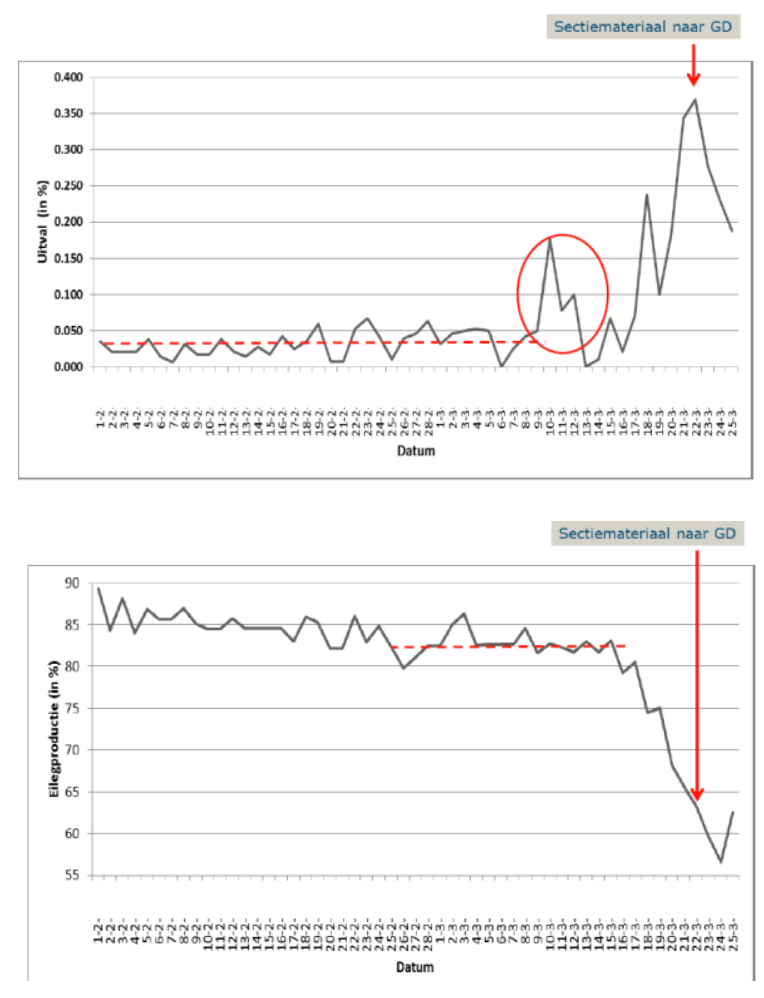

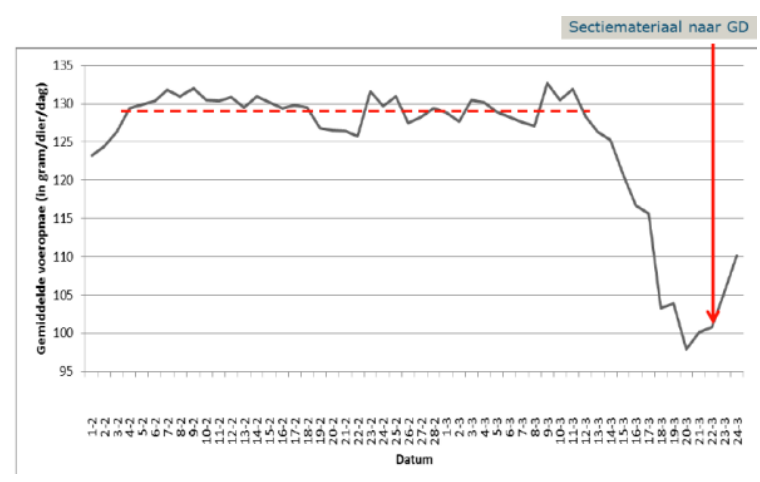

Figuur 7 Voorbeeld relatie tussen stijging in uitval, daling in voeropname en daling in eiproductie en moment van insturen van sectiemateriaal naar de GD op een bedrijf dat besmet is geraakt met LPAI (bron: Elbers en Van der Spek, 2015)

De analyse van Elbers en Van der Spek (2015) laat zien dat de wettelijk genoemde perioden, waarna verhoging in uitval respectievelijk dalingen in voeropname en eiproductie tot actie moeten leiden om een besmetting met (LP)AI uit te sluiten, in de praktijk op bedrijven die besmet zijn geraakt niet altijd 
zijn nageleefd. Tussen optreden van verhoogde uitval en/of dalingen in voeropname en eiproductie en uitsluitsel over een besmetting met AI-virus kon enkele dagen tot enkele weken zitten. Het is niet uit te sluiten dat binnen een periode van enkele weken een aanwezig LPAI-virus muteert naar een hoogpathogene variant.

De langste perioden worden waargenomen tussen een verhoging in uitval en het moment waarop daadwerkelijk kadavers ter sectie naar de GD worden gestuurd. Een verhoging in uitval $(0,5 \%$ in de voorgaande twee dagen) moet landelijk worden gemeld. De vraag is relevant hoe vaak op een leghennenbedrijf gemiddeld een dergelijke verhoging in uitval plaatsvindt en hoe vaak dat te wijten zal zijn aan een besmetting met LPAI-virus. Bij veel 'loos alarm' (geen LPAI-virusinfectie) zal de pluimveehouder minder gemotiveerd zijn om de betreffende uitvaltoename snel te melden. Er zijn verschillende factoren van invloed op de uitval. Het is bekend dat kippen met onbehandelde snavels heftig kunnen reageren op bepaalde stressoren, waardoor een grotere fluctuatie in uitval voor kan komen dan op bedrijven met kippen met behandelde snavels. Ook kan het merk kip van invloed zijn: er zijn merken waarbij de kippen soms ineens op een hoop lopen (het zogenaamde 'troepen'; dit is een erfelijk probleem), met veel uitval tot gevolg. De oorzaak voor dit type uitval is goed zichtbaar in de stal (en handig om te vermelden bij de centrale melding van verhoogde uitval). In opdracht van het ministerie van EZ onderzoekt Wageningen Bioveterinary Research (WBVR; voorheen CVI) in 2016 mogelijke nieuwe meldingsgrenzen voor uitval, waarbij mede gekeken wordt hoe vaak bij "normale" koppels zonder LPAI-virusintroductie verhogingen van sterfte worden gedetecteerd met deze nieuwe meldingsgrenzen (vals-alarm). Het lijkt in elk geval relevant om factoren zoals het type bedrijfssysteem (uitloop-geen uitloop), wel/geen behandelde snavels en het merk van de kippen bij de analyse te betrekken.

Woudenberg (2015) ontwikkelde een prototype systeem dat een pluimveehouder in de toekomst zou kunnen helpen bij het vroeg detecteren van LPAI-virusinfecties. De pluimveehouder moet hiervoor de productiegegevens op dagniveau in de computer bijhouden. Het eerste ontwerp van het systeem maakt een voorspelling van eiproductie voor de volgende dag. Die voorspelling is gebaseerd op bekende productiecurves, maar houdt ook rekening met specifieke kenmerken van het productiebedrijf, met meetgegevens van de afgelopen dagen, en met bijzondere omstandigheden (bijvoorbeeld hoge buitentemperatuur). Vroege detectie is gebaseerd op verschillen tussen de verwachte en de werkelijke waarden van eiproductie. Het systeem geeft bij overschrijding van bepaalde drempelwaarden aan dat er iets aan de hand kan zijn. Dat hoeft nog niet te betekenen dat er sprake is van een AI-virusbesmetting. In een volgende stap heeft Woudenberg op basis van expertkennis een eerste schets van een Bayesiaans netwerk ontwikkeld, dat op basis van o.a. klinische symptomen aangeeft of er een verhoogde kans is op LPAI-virusinfectie. In dit model worden zowel klinische symptomen bij levende kippen (bv. conjunctivitis of rochelende geluiden) als bevindingen van post-mortem onderzoek (bv. ontstoken trachea) meegenomen, evenals productiegegevens, klinische verschijnselen op koppelniveau (bv. een toename in grondeieren of bij elkaar kruipen van kippen) en de kans op insleep van AI-virus (Woudenberg, 2015). Het Bayesiaanse netwerk is volledig gebaseerd op expertkennis. De potentie bestaat om het systeem verder uit te bouwen naar een beslissingsondersteunend systeem voor NVWA-dierenartsen om het in de praktijk te kunnen toepassen bij het onderzoeken van klinische verdenkingen. Uitbouw van de tool naar een managementondersteunend systeem voor pluimveehouders verdient ook aandacht.

\subsection{De hygiënescan van de pluimveesector}

Naar aanleiding van de uitbraken eind 2014 hebben het pluimveebedrijfsleven en GD een hygiënescan opgezet, waarmee pluimveehouders uiteenlopende hygiënemaatregelen kunnen scoren: het is een digitale tool waarmee het hygiënemanagement voor alle typen pluimveebedrijven wordt gemonitord [bron: https://www.avined.nl/nieuws/hygienescan-operationeel]. Hiermee wil de sector het risico op introductie en verspreiding van ziekten, waaronder vogelgriep, verkleinen. Sinds 1 augustus 2015 hebben pluimveehouders binnen IKB de verplichting om 1 keer per jaar de hygiënescan voor hun bedrijf in te vullen. Het resultaat van de hygiënescan wordt uitgedrukt in scores. De resultaten zijn voor eigen gebruik door de pluimveehouder om de bedrijfshygiëne te optimaliseren. Daarnaast ontvangt de bedrijfseigen dierenarts het resultaat van de scan via de CRA-database, en wordt deze 
meegenomen in de (wettelijk verplichte) jaarlijkse bespreking van het bedrijfsgezondheidsplan (BGP). De sector wil de resultaten op termijn verwerken tot benchmarkrapporten (anoniem), zodat op sectorniveau kan worden gezien op welke onderdelen goed wordt gescoord en waar verbeterpunten liggen.

De hygiënescan kent een uitgebreid aantal maatregelen dat generiek is voor alle typen pluimveebedrijven. Het betreft maatregelen met betrekking tot ongediertebestrijding, afscheiding van het bedrijfsterrein, hygiëne van het bedrijfsterrein, bedrijfshygiëne, stalhygiëne en hygiënische maatregelen met betrekking tot voertuigen, materialen en personeel. Het gaat hier om de bekende preventieve maatregelen passend binnen een goede biosecurity, aangevuld met preventieve maatregelen voor risicofactoren die naar aanleiding van de analyses van HPAI-uitbraken nadruk hebben gekregen. Daarnaast zijn onder andere extra voorschriften opgenomen voor bedrijven met vrije uitloop. Dit betreft de volgende (nieuwe) maatregelen:

- De uitloop is goed afgegrensd, zodat pluimvee vanuit naburige uitlopen en/of watervogels vanuit waterpartijen de uitloop niet kunnen betreden.

- Aan de stalzijde van de uitloop is een droge strook van minimaal 3 meter breed.

- Aansluitend aan deze strook is beplanting aangelegd (minimaal 5 meter breed) met daarin meerjarige beplanting die bijdraagt aan het weren van watervogels.

- Bij betreden van de uitloop vanuit het bedrijfsterrein en andersom wordt gewisseld van schoeisel.

- Bij het verlaten van de uitloop worden de handen gewassen.

In januari 2016 heeft de pluimveesector een enquête uitgezet naar het nut en gebruiksgemak van de hygiënescan onder de in totaal 1145 pluimveehouders die op dat moment een hygiënescan hadden ingevuld (bron: AVINED). Dit betekent dat 6 maanden na introductie van de hygiënescan door de sector ca. 30\% van de pluimveebedrijven de scan heeft ingevuld (of laten invullen door zijn dierenarts). Door 435 pluimveehouders (d.i. ca. 38\% van de benaderde pluimveehouders) is ten minste een deel van de enquêtevragen beantwoord. Ruim de helft van de respondenten geeft aan de bedrijfshygiëne op de eigen locatie in de afgelopen 12 maanden (d.i. januari t/m december 2015) te hebben verbeterd. De meeste verbeteringen werden doorgevoerd in de maanden na introductie van de hygiënescan (augustus $\mathrm{t} / \mathrm{m}$ december 2015). Ruim 75\% van de respondenten vindt dat de hygiënescan heeft geleid tot een hogere bewustwording van de hygiënestatus op het bedrijf. De inhoud van de hygiënescan wordt door ruim 66\% van de respondenten met een 7 of hoger gewaardeerd (op een schaal van 10). Op de vraag over de bruikbaarheid van de resultaten van de hygiënescan hebben slechts 63 respondenten gereageerd: ruim 57\% stond hier neutraal tegenover en ruim $31 \%$ vond de uitkomsten niet bruikbaar. Een kleine $74 \%$ van de 435 respondenten vindt het voor de hele sector wel belangrijk dat iedereen de hygiënescan jaarlijks invult.

Soms lijken er wat tegenstrijdige antwoorden te zijn gegeven: een relatief hoge waardering voor de inhoud van de scan, relatief lage respons op en waardering voor de bruikbaarheid, maar veel respondenten zijn wel voor jaarlijks verplicht invullen van de scan. Conclusie op dit moment kan zijn dat het invullen van de hygiënescan bij een deel van de pluimveehouders in elk geval heeft geleid tot een hogere bewustwording van de hygiënestatus van het eigen bedrijf.

Wij geven enkele overwegingen bij de hygiënescan:

- De generieke maatregelen in de hygiënescan dekken grotendeels de bekende risicofactoren en mogelijke preventieve maatregelen met betrekking tot insleep van HPAI-virus op bedrijven zonder vrije uitloop. Vanuit de bevindingen van Velkers et al. (2015) zijn drie aanvullingen relevant:

- In de hygiënescan wordt aangeraden het gras rondom stallen kort te houden. Velkers et al. pleiten ervoor om (de noodzaak tot) grasmaaien rond stallen te beperken omdat het tot opwervelen van uitwerpselen van wilde vogels en ongedierte zou kunnen leiden: verharden van alle grond direct grenzend aan de stallen heeft daarom de voorkeur.

- Eisen stellen of garanties vragen dat strooisel en ruwvoer niet of beperkt blootgesteld is geweest aan uitwerpselen van wilde vogels.

- Ongediertebestrijding laten uitvoeren door een professioneel bedrijf.

- De extra maatregelen voor bedrijven met vrije uitloop zijn ingegeven vanuit het streven om watervogels uit de uitloop te weren en het risico op introductie van virus vanuit de uitloop naar de stallen en het bedrijfsterrein te beperken. De inrichting van de uitloop kan hier een belangrijke 
factor in zijn. Binnen de randvoorwaarden van gezondheid mens-dier dient de inrichting van de uitloop ook tegemoet te komen aan de doelstelling ervan, namelijk optimaal gebruik door het pluimvee. Bepaalde inrichtingselementen zoals bomen, struiken en andere schuilplaatsen kunnen het gebruik van de uitloop door de kippen bevorderen en gelijker tijd de uitloop minder aantrekkelijk maken voor watervogels. Een strook met (meerjarige) beplanting hoeft zich dan ook niet te beperken tot een strook van minimaal 5 meter breedte. Op een aantal bedrijven wordt ervaring opgedaan met beplanting van een groot deel van de uitloop met wilgen of miscanthus (olifantsgras). Daarnaast kunnen gazen afscheidingen tussen uitloop en waterpartijen voorkomen of bemoeilijken dat eenden in de uitloop komen.

- Bepaalde preventieve maatregelen van de hygiënescan vragen om een bedrijfsspecifieke invulling, zoals de maatregel over toepassing van het schone-vuile weg principe.

- De hygiënescan bestaat voor een belangrijk deel uit goed controleerbare harde voorzieningen en situaties (bijvoorbeeld afwezigheid mest van een vorige ronde) en controleerbare aanwezigheid van protocollen en registraties. Maar het bestaat ook uit minder goed of niet controleerbare gewenste werkwijzen, zoals reinigen en ontsmetten van de kadaverplaat na bezoek Rendac, altijd omkleden in staleigen kleding en schoeisel, geen huisdieren in voorlokalen, de uitvoering van ongediertebestrijding en dergelijke. Het wel of niet voldoen aan maatregelen wordt jaarlijks ingevuld door de pluimveehouder en/of dierenarts en krijgt een weging mee in de scan, wat leidt tot een eindscore van het bedrijf. Aan de eindscore zijn op dit moment geen consequenties verbonden. Indien de bedrijfsscores in de toekomst worden benut voor benchmark van bedrijven of als aanleiding voor verplichte verbeterplannen op de bedrijven, is het belangrijk om te zorgen dat de maatregelen die in de scan staan eenduidig te interpreteren en controleerbaar zijn. Een aantal maatregelen zal dan naar verwachting moeten vervallen, of buiten de score moeten worden gehouden.

- De hygiënescan richt zich met generieke maatregelen op de situatie binnen de grenzen van het bedrijfsterrein. Het houdt geen rekening met geografische kenmerken van het gebied waarin het bedrijf zich bevindt (wel/geen waterrijk gebied; pluimveedicht/-arm gebied; wel/niet trekvogelroutes) en met situering van stallen en het bedrijfsterrein ten opzichte van de buitenwereld. Geospatiale en bedrijfsspecifieke kenmerken zouden aanleiding kunnen geven om bepaalde preventieve maatregelen een zwaardere weging mee te geven dan andere (gezien de factor 'kleigrond' als risicofactor voor een LPAI-besmetting op uitloopbedrijven zou een gedifferentieerd beleid op dit punt bijvoorbeeld een optie kunnen zijn). Dit kan een punt van aandacht zijn bij verdere uitbouw en inzet van het instrument hygiënescan.

\subsection{FAO 3-zone-biosecuritymodel}

De FAO (2015) heeft ter preventie van een introductie van HPAI-virus een 3-zone biosecurity-model ontwikkeld, dat een pluimveebedrijf naar biosecurity-risico's indeelt in drie gescheiden zones. Uiteenlopend van de externe gebieden met een hoog besmettingsrisico (de rode zone), naar de bedrijfsfunctionele gebieden met een gemiddeld risico (de gele zone), naar de schone, sterk afgeschermde en beperkt toegankelijke groene zone waar de dieren verblijven. Voor toegang van de rode naar de gele zone moet men douchen en volledig omkleden in bedrijfseigen kleding en schoeisel. Voor toegang tot de groene zone moet men o.a. opnieuw van schoeisel wisselen. Het model is in Indonesië getest. Toepassing van dit volgens de FAO eenvoudige en kosteneffectieve model heeft volgens deelnemers op zes commerciële leghennenbedrijven sinds 2012 als neveneffect geleid tot een reductie in ziekte-incidentie en uitval op de bedrijven, betere productieresultaten en een toename in inkomen. 


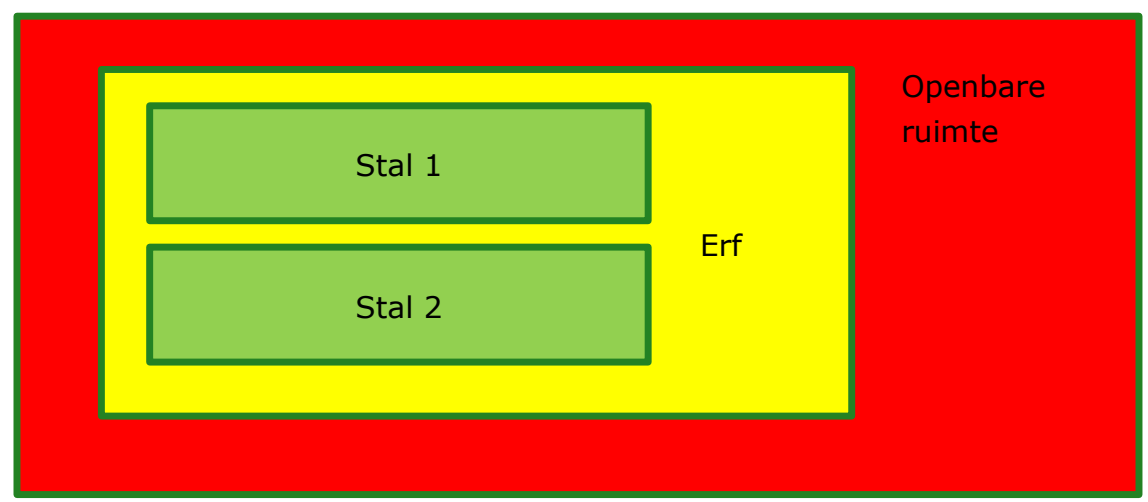

Figuur 8 Het 3-zone-biosecuritymodel van de FAO (FAO, 2015)

Het 3-zone-biosecurity model vertoont duidelijke overeenkomsten met uitgangspunten van ons schone-vuile weg principe, maar het 3-zone model heeft wellicht als voordeel dat het beter is te visualiseren en uit te leggen aan individuele pluimveehouders. Met behulp van rode, gele en groene zones kan voor ieder bedrijf 'op maat' worden vastgesteld wat de hoog-risico en gemiddeld-tot-laag risicogebieden zijn, en welke preventieve maatregelen binnen een risicogebied en op de overgangen tussen de rode, gele en groene zones specifiek voor dit bedrijf van belang zijn. 


\section{$5 \quad$ Kennis over bevorderen van gewenst (preventief) gedrag}

In dit hoofdstuk vatten we actuele kennis over sociaaleconomische ${ }^{2}$ en gedragspsychologische factoren (o.a. mindset) samen. Deze factoren beïnvloeden implementatie en naleving van maatregelen op het gebied van AI-preventie en vroegdetectie in de praktijk. Tevens gaan we in op mogelijkheden om via een integrale inzet van verschillende instrumenten gewenst (preventief) gedrag te ondersteunen.

\subsection{Sociaaleconomische criteria}

In een evaluatieraamwerk dat het LEI op verzoek van EZ (Bondt et al., 2016) heeft gemaakt voor inschatting van de effectiviteit van beleidsopties voor bestrijding van ESBL, is de sociaaleconomische context een belangrijke pijler. Deze wordt aan de hand van de volgende criteria beoordeeld:

$>$ De kosteneffectiviteit van de te implementeren maatregelen op het bedrijf (kosten versus baten);

> De praktische haalbaarheid van maatregelen;

$>$ De relevantie van maatregelen op sectorniveau;

$>$ De maatschappelijke impact van maatregelen;

$>$ Eventuele ongewenste neveneffecten van de maatregelen.

Dit zijn ook bruikbare criteria voor beoordeling van sociaaleconomische aspecten in handelingsperspectief voor AI-preventie. De kosteneffectiviteit en praktische haalbaarheid van interventies en maatregelen spreken voor zich. De relevantie van maatregelen op sectorniveau kan het individuele bedrijfsbelang overstijgen. Dat geldt zeker in het geval van vogelgriep, waarbij een uitbraak op een individueel bedrijf belangrijke (export-)consequenties kan hebben op sectoraal, regionaal en/of landelijk niveau. Maatschappelijke acceptatie van te nemen maatregelen is feitelijk een randvoorwaarde. De maatschappelijke impact van maatregelen kan bestaan uit materiële en immateriële kosten en baten. Preventie ten aanzien van introductie van LPAI/HPAI-virus op pluimveebedrijven is van groot belang voor de samenleving gezien het zoönotische karakter ervan. Maatschappelijke impact van maatregelen is aanwezig op bijvoorbeeld het terrein van economie, volksgezondheid, natuur (wilde vogels) en milieu. Maatregelen dienen ook te worden beoordeeld op mogelijke ongewenste neveneffecten. Te implementeren maatregelen op het gebied van AIrisicoreductie moeten geen (onaanvaardbare) negatieve effecten (afwentelingen) hebben op andere maatschappelijke relevante domeinen, zoals dierenwelzijn of milieu.

Voor succesvolle interventies is het belangrijk dat de sociaaleconomische condities geoptimaliseerd zijn. Handelingsperspectief voor de pluimveesector in AI-preventie hangt dus mede af van de beoordeling van mogelijke interventies en maatregelen op sociaaleconomische criteria.

Naast sociaaleconomische factoren zijn gedragskenmerken en persoonlijke voorkeuren van veehouders van belang voor de keuze van interventies en maatregelen.

\footnotetext{
2 De sociologen Bourdieu (1986) en Coleman (1990) zagen sociaaleconomische status als een functie van drie aspecten: 1) materiële omstandigheden, 2) vaardigheden, capaciteiten en kennis en 3) het sociale netwerk en de status en macht van mensen in dat netwerk. Elk van de indicatoren meet in meer of mindere mate een deel van de dimensies van sociaaleconomische status.
} 


\subsection{Gedragspsychologische aspecten}

Intenties voorafgaand aan (nieuw) gedrag

Mensen blijken niet altijd weloverwogen en goed geïnformeerd voor een bepaald gedrag te kiezen. En vaak niet te handelen zoals mag worden verwacht op basis van puur rationele gronden (Tiemeijer et al. 2009). Evenmin nemen mensen altijd de moeite om uit te zoeken wat de beste handelingsoptie is. Voor effectieve gedragsverandering is het belangrijk dat mensen intenties vormen ten gunste van het nieuwe gedrag (Ajzen, 1991). Om gewenst gedrag van pluimveehouders in reductie van de risico's op AI-uitbraak te kunnen ondersteunen en bevorderen is het voor beleidsmakers binnen de pluimveesector nuttig om een beeld te hebben van de intenties van pluimveehouders ten aanzien van insleeppreventie van AI-virus. Dan kan vervolgens worden nagegaan hoe beweging in de gewenste richting kan worden ondersteund (uitvoeringsstrategieën). De intentie om een bepaald gedrag uit te voeren kan men afleiden aan de hand van drie kenmerken (Ajzen, 1991; Bondt et al., 2016):

$>$ Iemands houding of attitude ten opzichte van het gedrag;

Het is een afweging van alle voor- en nadelen die een persoon aan het gedrag verbonden acht. En niet alleen op basis van verstandelijke overwegingen, maar ook op basis van ingesleten gewoontes en niet-rationele overtuigingen (Tiemeijer et al., 2009).

Is de pluimveehouder persoonlijk gemotiveerd om met strikte maatregelen AI buiten de deur te houden? Hoe belangrijk of effectief vindt hij de maatregelen om het doel, AI-insleep voorkómen, te bereiken?

$>$ De subjectieve norm of de sociale dimensie van het gedrag;

Dit is de sociale druk die de omgeving uitoefent op het gedrag of de sociale druk die men ervaart om bepaald gedrag uit te voeren. Interessant is overigens dat veel voorkomend gedrag in de omgeving vaak aan blijkt te zetten tot navolging van ditzelfde gedrag (Tiemeijer et al., 2009).

Hoe denkt de pluimveehouder dat mensen uit zijn sociale omgeving oordelen over het uitvoeren van strikte preventiemaatregelen en hoe belangrijk ze het vinden?

$>$ De inschatting van de effectiviteit van het eigen gedrag en de controle over de uitvoering (zelfeffectiviteit/wilskracht);

Hierbij spelen vroegere ervaringen met hetzelfde of vergelijkbaar gedrag vaak een rol. Dit roept vragen op zoals: Acht ik mijzelf in staat om de gewenste maatregelen en het gedrag daadwerkelijk uit te voeren? Houd ik het gewenste gedrag consequent vol? Kan ik er voldoende sturing op (blijven) zetten?

\section{Persoonlijkheidskenmerken en de boodschap}

Gerichte voorlichting of educatie kan de intenties van mensen beïnvloeden. Om effect te kunnen hebben is het belangrijk dat in een overtuigingsstrategie rekening wordt gehouden met verschillen in persoonlijkheidskenmerken van de ontvangers van de boodschap, in dit geval pluimveehouders. Faddegon (2009) noemt vier persoonlijkheidskenmerken waarin mensen wezenlijk kunnen verschillen en die het keuzegedrag kunnen bepalen (met de kanttekening dat het gedrag natuurlijk tevens afhankelijk is van de situatie waarin men zich bevindt):

a) de mate waarin iemand graag over (complexe) zaken nadenkt en informatie absorbeert ('need for cognition'),

b) de mate waarin iemand kan omgaan met onzekerheid en tweeslachtigheid ('need for closure),

c) de mate waarin iemand streeft naar groei en vooruitgang (promotiefocus) dan wel naar veiligheid en het vermijden van risico's (preventiefocus) en,

d) de mate waarin iemand beschikt over zelfdiscipline (zelfcontrole) ${ }^{3}$.

\footnotetext{
${ }^{3}$ Voor het in kaart brengen van deze persoonlijkheidskenmerken bestaan verschillende maatlatten.
} 
Mensen met een hoge 'need for cognition' laten zich vooral overtuigen op basis van de kwaliteit van de (goed en uitgebreid beschreven) argumenten. Mensen met een lage 'need for cognition' zijn gevoeliger voor eenvoudige aanwijzingen en eenvoudige beslisregels, zoals de geloofwaardigheid en autoriteit van degene die de boodschap brengt.

Mensen met een hoge behoefte aan snel uitsluitsel of een definitief antwoord (een hoge 'need for closure') zijn minder geneigd om verschillende invalshoeken te overwegen voordat ze een oordeel vellen en zijn tegelijker tijd zekerder over hun oordeel dan mensen met een lage 'need for closure'. Mensen met een promotiefocus zijn sterk gericht op vooruitgang en groei en mensen met een preventiefocus zijn vooral gericht op veiligheid en het vermijden van verlies. De eerste groep is dan ook vooral aanspreekbaar op wat een nieuw gewenst gedrag kan opleveren (positieve uitkomst), de tweede groep vooral op het verlies dat kan ontstaan als het gewenste gedrag niet wordt ingezet (de negatieve uitkomst van het bestaande gedrag).

Onder zelfcontrole (of wilskracht) verstaat men de capaciteit om de eigen reacties zo te controleren dat gewenst gedrag optreedt en ongewenst gedrag uitblijft.

Mensen zijn gevoelig voor wat andere mensen doen. Daar kan in een communicatiestrategie gebruik van worden gemaakt. Dat wil zeggen, benadrukken hoeveel mensen het gewenste gedrag al uitvoeren in plaats van de nadruk te leggen op het risicovolle gedrag. Rijnja et al. (2009) voegen nog twee elementen toe die in algemene zin belangrijk kunnen zijn in een communicatiestrategie: emotie en vertrouwen. Het ene gaat over contact maken met emotionele onderstromen voor gedrag: een boodschap waarin 'slachtoffers' van AI-uitbraak vertellen over hun ervaringen zou een grotere invloed kunnen hebben op de inschatting van risico's door andere pluimveehouders dan boodschappen die alleen feiten bevatten. Het andere gaat over het vertrouwen dat ontvangers van een boodschap hebben in de zender, en dat ook een hele belangrijke factor kan zijn voor een effectieve communicatie over AI-preventie.

De verschillen tussen individuen in persoonlijkheidskenmerken maken in elk geval duidelijk dat overtuigingsstrategieën zorgvuldig moeten zijn afgestemd op de kenmerken van de doelgroep en individuele verschillen daarbinnen.

\section{Ongewenst gewoontegedrag doorbreken}

Het hebben van een intentie wil nog niet zeggen dat het gedrag ook daadwerkelijk wordt uitgevoerd. Ingesleten gewoontes kunnen een belangrijke verstorende factor zijn (Tiemeijer et al., 2009).

Gewoontes liggen sterk verankerd in het onderbewuste: voorlichting en educatie hebben er weinig vat op. Het is niet eenvoudig om mensen gewoontegedrag af te leren, en het onderzoek naar effectieve methoden is nog beperkt. Toch lijken er mogelijkheden te zijn. Eén daarvan is momenten te gebruiken waarop mensen nieuwe afwegingen maken. Zo zou nieuwbouw op een pluimveebedrijf een goed moment kunnen zijn om bepaalde ingesleten gewoontes ten aanzien van preventie en hygiëne bij te stellen naar meer gewenst gedrag. Een andere manier is om mensen te stimuleren nieuw gedrag heel bewust te plannen (ook wel implementatie-intenties genoemd). Niet alleen de intentie hebben om voortaan zelf strikte hygiëneregels in acht te nemen bij het betreden van stallen, maar zelf ook een concreet uitvoeringsplan formuleren waarin staat wanneer, waar en hoe men het nieuwe gedrag gaat uitvoeren. Op die manier kunnen situaties (wanneer) en locaties (waar) helpen om het gewenste gedrag iedere keer opnieuw te 'triggeren'. Dergelijke implementatie-intenties kunnen ook gezamenlijk in groepsverband (bijvoorbeeld in studieclubs van pluimveehouders) worden opgesteld. Voordeel daarvan is dat groepsnormen het maken van het plan en de effectiviteit ervan kunnen bevorderen.

\section{Nudges of kleine duwtjes in de gewenste richting}

Als interessante nieuwe benadering om ongewenst gewoontegedrag te helpen doorbreken, noemt men het activeren van gewenst gedrag door bijvoorbeeld eenvoudige voorzieningen in de omgeving. Hier komen ook 'nudges' in beeld. Het begrip 'nudge' (Thaler en Sunstein, 2008) staat de laatste jaren sterk in de belangstelling van de gedragswetenschappen. Een eenduidige definitie ontbreekt, maar 'nudges' zouden kunnen worden beschreven als elementen in ontwerp, vormgeving, presentatie of context die iemands keuze en gedrag in een gewenste richting veranderen zonder dat er sprake is van ge- of verboden of dwang: 'nudges' zijn eenvoudig en gemakkelijk te vermijden voor iemand (WRR 2014). Een subtiele manier van gedragsbeïnvloeding dus. Fruit op ooghoogte plaatsen in de schoolkantine is bijvoorbeeld een 'nudge' om gezonder eetgedrag te stimuleren. Het is interessant om na te gaan of er effectieve 'nudges' zijn om gewenst preventief gedrag in relatie met vogelgrieppreventie op pluimveebedrijven te stimuleren. 


\subsection{Samenhang in inzet van instrumenten}

Jansen et al. (2012) onderzochten het belang van de mindset van melkveehouders in relatie tot mastitispreventie, waarbij mindset twee belangrijke drijvers bleek te hebben: de gepercipieerde dreiging ('Heb ik een probleem') en de gepercipieerde effectiviteit van preventieve maatregelen ('Kan ik het probleem gemakkelijk oplossen'). 'Heb ik een probleem' is ook in relatie met AI een relevante vraag. De belangrijkste uitdaging is om te zorgen dat in alle tijden en zeker in 'verhoogd-risicotijd' (bv. de periode van de vogeltrek in de relevante regio's) pluimveehouders zodanig worden geprikkeld dat AI-preventie goed en consequent wordt uitgevoerd, zodat het risico op insleep van virus minimaal is. Hiermee bezig zijn moet ook positief werken op het buiten de deur houden van andere pluimveeziektekiemen. Zodra een uitbraak van hoogpathogene vogelgriep is gedetecteerd, bevinden in principe alle pluimveebedrijven zich in 'oorlogstijd' en zullen een extra stringent hygiënebeleid gaan doorvoeren.

Rijnja et al. (2009) geven voorbeelden van kansrijke benaderingen voor gedragsverandering via samenwerking tussen drie typen sturingsinstrumenten, de preek (voorlichting en scholing), de peen (stimulansen en voorzieningen) en de zweep (regelgeving en sancties). Jansen et al. (2012) noemen vijf instrumenten die (samenhangend) in acht moeten worden genomen om een gedragsverandering te kunnen bewerkstelligen. Dit is het zogenaamde R.E.S.E.T. model: de $\mathrm{R}$ van regelgeving, de $\mathrm{E}$ van Educatie, de $\mathrm{S}$ van sociale druk, de $\mathrm{E}$ van economische prikkels, en de $\mathrm{T}$ van ondersteunende tools. Daarbij benadrukken de auteurs dat veehouders verschillende leerstijlen hebben en een voorkeur hebben voor communicatie 'op maat'. Om zoveel mogelijk veehouders te bereiken is daarom een specifieke combinatie van acties en communicatiestrategieën nodig.

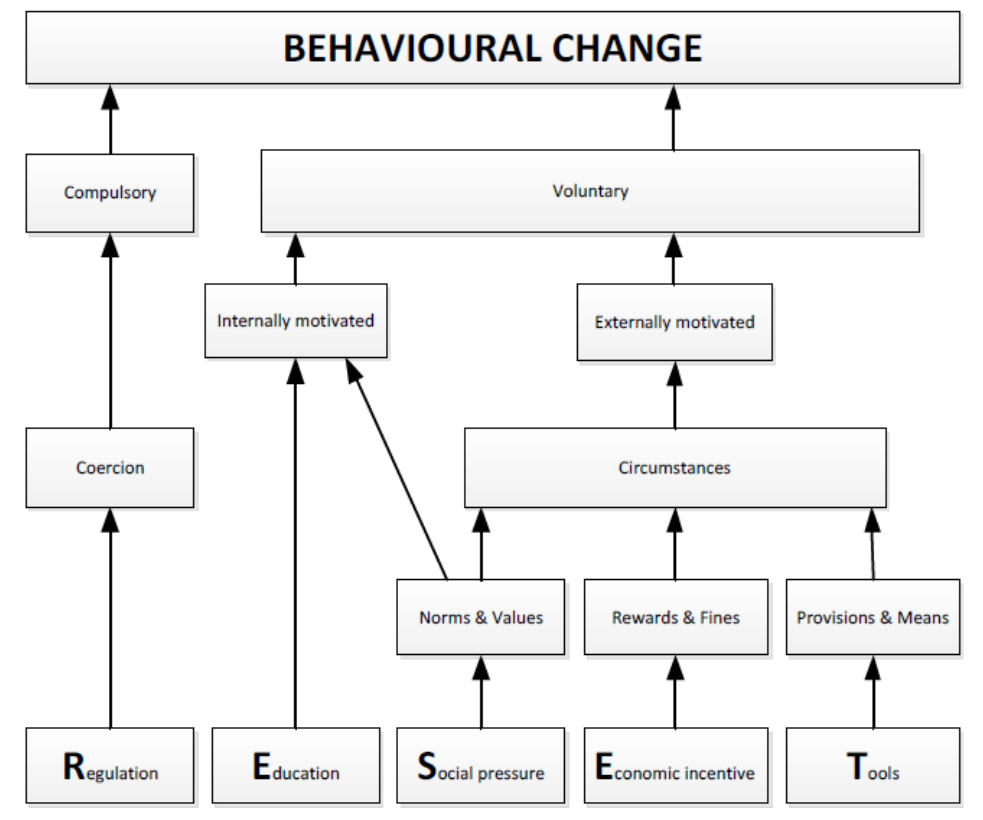

Figuur 9 Het R.E.S.E.T. model: Gedragsverandering door een combinatie van strategieën (bron: Jansen et al., 2012)

Regelgeving $(R)$, publiek of privaat, kan een direct effect hebben. Denk bijvoorbeeld aan de verplichte meldingen van AI-verdenkingen en de IKB-hygiënevoorschriften waaronder het verplicht doorlopen van de GD-hygiënescan. De mogelijkheid om met regelgeving gewenst gedrag af te dwingen hangt af van het draagvlak voor de regelgeving en van een goede handhaving.

Educatie (E) wordt als instrument vaak ingezet, maar zal vaak pas effectief zijn als het wordt afgestemd op de leerstijlen van de veehouders. Communicatie/educatie is overigens ook het smeermiddel tussen de verschillende instrumenten.

Bevorderen van sociale druk (S) wordt gezien als een krachtig instrument: als de sociale druk hoog genoeg is, hebben de andere instrumenten minder effect. Jansen et al geven aan dat dierenartsen en andere bedrijfsadviseurs belangrijk zijn in het verhogen van de sociale druk en om de veehouder een beeld te geven van wat de sociale norm is en wat afwijkt van normaal. Daarbij moeten bedrijfsadviseurs goed met elkaar afstemmen en uiteraard een gelijkluidende boodschap afgeven. 
Economische prikkels (E) kunnen van belang zijn. Met een bonus-malus systeem kan bepaald gedrag worden bevorderd of ontmoedigd, vooral omdat het een soort sociale norm zichtbaar maakt. Het kan ook contraproductief werken: zolang men aan de goede kant van de gewenste 'norm' zit

(bijvoorbeeld: een bepaalde score op de hygiënescan) kan men een verdere inspanning op preventief gebied onnodig vinden. Van subsidieregelingen op bepaalde investeringen kan een stimulerend effect uitgaan. Van economische prikkels is ook sprake als veehouders zien welke economische voordelen het implementeren van bijvoorbeeld preventieve maatregelen blijkt te hebben. Of indien aan implementatie van bepaalde maatregelen een economisch voordeel wordt gehangen. Voorbeeld: ingestuurde monsters na toename in de uitval ( $+0.5 \%$ per dag in de afgelopen 2 dagen) niet alleen testen op AI-virus, maar bij negatieve uitslag voor AI bij wijze van service aan de veehouder tevens een analyse op mogelijke andere oorzaken voor de verhoogde uitval uitvoeren (bijvoorbeeld IB of Eimeria spp.). Bij economische prikkels past wel de kanttekening dat mensen vaak niet als homo economicus blijken te handelen (zie ook 5.2).

Tools $(T)$ kunnen bijvoorbeeld bestaan uit technische voorzieningen, hulpmiddelen, protocollen, checklisten en dergelijke, en kunnen het voor de veehouder makkelijker maken om bepaald gewenst gedrag uit te voeren. Voorbeelden zijn goed ontworpen voorruimten, met praktische voorzieningen en duidelijke instructiebordjes; helder aangegeven looplijnen op het bedrijf; per stal een bepaalde kleur laarzen en overalls; checklisten met risicofactoren en mogelijke verbetermaatregelen. Dit kunnen ook tools zijn die het gedrag van de veehouder onbewust in een bepaalde richting sturen (zie 'nudges' bij 5.2). Jansen et al geven aan dat tools alleen werken als ze in combinatie met de andere instrumenten worden gebruikt. 


\section{Literatuur}

Ajzen, I. 1991. Theories of Cognitive Self-RegulationThe theory of planned behavior. Organizational Behavior and Human Decision Processes, 50, 179-211.

Bestman M., R. Loefs, H. de Vries, G-J van der Burgt, 2008. Kippenuitloop Gezond en Groen. Inspiratie en ideeën voor ontwerp en uitvoering. Brochure Louis Bolk Instituut.

Bestman, M., 2014. KAT kijkt strenger. Pluimveehouderij 44 jaargang-20 juni 2014.

Bestman, M.W.P. 2015. Bomen voor Buitenkippen. Louis Bolk Instituut, Driebergen. 24 p. http://www.louisbolk.org/downloads/3048.pdf

Bondt N., M. van Asseldonk and R. Bergevoet, 2016. ESBL Evaluation framework. LEI Wageningen UR. Report 2016-020. http://dx.doi.org/10.18174/385287

Bouwstra, R., \& Elbers, A. R. W. (2014). Relatieve risico's van introductie van laag-pathogene aviaire influenza virus infecties op verschillende typen pluimveebedrijven in Nederland, 2007-2013. 6 maart 2014.

Bouwstra, R. J., Koch, G., Heutink, R., Harders, F., van der Spek, A. N., Elbers, A. R. W., \& Bossers, A. (2015). Full genome sequence of HPAI H5N8 outbreak strains provide evidence for four separate introductions and one between-poultry farm transmission in the Netherlands, 2014. EuroSurveillance, 20(26), 21174.

EFSA (2008). Animal health and welfare aspects of avian influenza and the risk of its introduction into the EU poultry holdings. Scientific Opinion of the Panel on Animal Health and Welfare. The EFSA Journal, 715, 1-162.

Elbers, A., \& Van der Spek, A. (2015). Analyse van productiegegevens van legpluimveebedrijven met een introductie van LPAI virus (afgelopen 5 jaar).

Elbers, A. R. W., de Wit, J. J., Hulsbergen, H. B. A., van der Spek, A. N., Fabri, T., \& Koch, G. (2008). 'Avian Influenza surveillance in poultry in the Netherlands between 2004-2006'. Paper presented at the World Veterinary Poultry Congress, Beijing, China. http://library.wur.nl/WebQuery/wurpubs/371075

Elbers, A. R. W., Gorgievski-Duijvesteijn, M. J., K., Z., \& Koch, G. (2010). To report or not to report: a psychosocial investigation aimed at improving early detection of Avian Influenza outbreaks. Rev. sci. tech. OIE, 29(3), 435-449.

Elbers, A. R. W., Holtslag, J. B., Bouma, A., \& Koch, G. (2007). Within-flock mortality during the highpathogenicity Avian Influenza (H7N7) epidemic in the Netherlands in 2003: implications for an early detection system. Avian Dis. , 51((1 Suppl)), 304-308.

Faddegon K., 2009. 'Psychologische verschillen in keuzegedrag', in: Tiemeijer, W. L., Thomas, C. A., \& Prast, H. M. r. (2009). De menselijke beslisser: over de psychologie van keuze en gedrag: AMSTERDAM UNIVERSITY PRESS.

FAO, 2015. 3-Zone Biosecurity model, presented at the fourth National Poultry Farmers' Seminar on July 30th, 2015 as part of FAO ECTAD Indonesia participation in the Indolivestock 2015 Expo and Forum, Surabaya.

http://www.fao.org/ag/againfo/programmes/en/empres/news_060815b.html

FES-AI consortium. (2012). Vogelgriep ontrafeld: Resultaten FES-AI onderzoeksprogramma. http://www.wageningenur.nl/upload_mm/c/8/7/faff1584-2289-4637-b5028527a28d06b3_Vogelgriep_Ontrafeld_20121024.pdf

Fouchier, R. A., Schneeberger, P. M., Rozendaal, F. W., \& al., e. (2004). 'Avian influenza A virus (H7N7) associated with human conjunctivitis and a fatal case of acute respiratory distress syndrome'. Paper presented at the Proc Natl Acad Sci, USA.

GD, 2015. Hygiënescan v0.91.

Gonzales, J. L., Stegeman, J. A., de Wit, J. J., Koch, G., \& Elbers, A. R. W. (2013). Differences in risk of introduction of a LPAIv infection between poultry production sectors and outdoor/indoor farming systems in the Netherlands. Influenza and other respiratory diseases, 7, 6-10.

Jansen J., R. Wessels and Th. Lam, 2012. How to RESET farmers mindset. Conference paper Countdown Symposium, Melbourne Australia 19 July 2012. - Melbourne Australia: Dairy Australia, 2012 - p. $23-27$. 
Koch, G., Elbers, A.R.W. (2006). Outdoor ranging of poultry: a major risk factor for the introduction and development of high pathogenicity avian Influenza. Neth. J. Agric. Sci. 54 (2): 179-194.

Rijnja G., E. Seydel en J. Zuure, 2009. 'Communiceren vanuit de context: naar effectievere overheidscommunicatie', in: Tiemeijer, W. L., Thomas, C. A., \& Prast, H. M. r. (2009). De menselijke beslisser: over de psychologie van keuze en gedrag: AMSTERDAM UNIVERSITY PRESS.

Stegeman, J. A., Bouma, A., Elbers, A. R. W., van Boven, M., de Jong, M. C. M., \& Koch, G. (2004). The Avian Influenza A virus (H7N7) epidemic in the Netherlands in 2003: course of the epidemic and effectiveness of control measures. J. Infect. Dis. , 190, 2088-2095.

Thaler, R.H. en Sunstein, C.R. 2008. Nudge: Improving decisions about health, wealth, and happiness, Yale University Press, New Haven, CT, 2008, 293 pp

Tiemeijer, W. L., Thomas, C. A., \& Prast, H. M. r. (2009). De menselijke beslisser: over de psychologie van keuze en gedrag: AMSTERDAM UNIVERSITY PRESS.

USDA, Veterinary Services, 2015. Epidemiologic and Other Analyses of HPAI-Affected Poultry Flocks: september 9, 2015 Report https://www.aphis.usda.gov/animal_health/animal_dis_spec/poultry/downloads/EpidemiologicAnalysis-Sept-2015.pdf

Van der Goot, J., Elbers, A., Bouwstra, R., Fabri, T., Van Wijhe-Kiezebrink, M., \& Van Niekerk, T. (2015). Risicofactoren voor introductie van laag-pathogeen aviaire influenza virus op legpluimveebedrijven met vrije uitloop in Nederland. CVI Rapport 15/CVI0078.

Velkers, F., Elbers, A., Bouwstra, R., \& Stegeman, A. (2015). H5N8 in Nederland in 2014: Een nadere blik op de uitbraken (vertrouwelijk rapport)

Woudenberg, S.P.D., 2015. Bayesian tools for Early Disease Detection. PhD-Proefschrift Universiteit Utrecht. 14 oktober 2015. SIKS Dissertation Series No. 2015-25.

WRR (2014). Met kennis van gedrag beleid maken. Amsterdam University Press (Vol. rapport 92). 


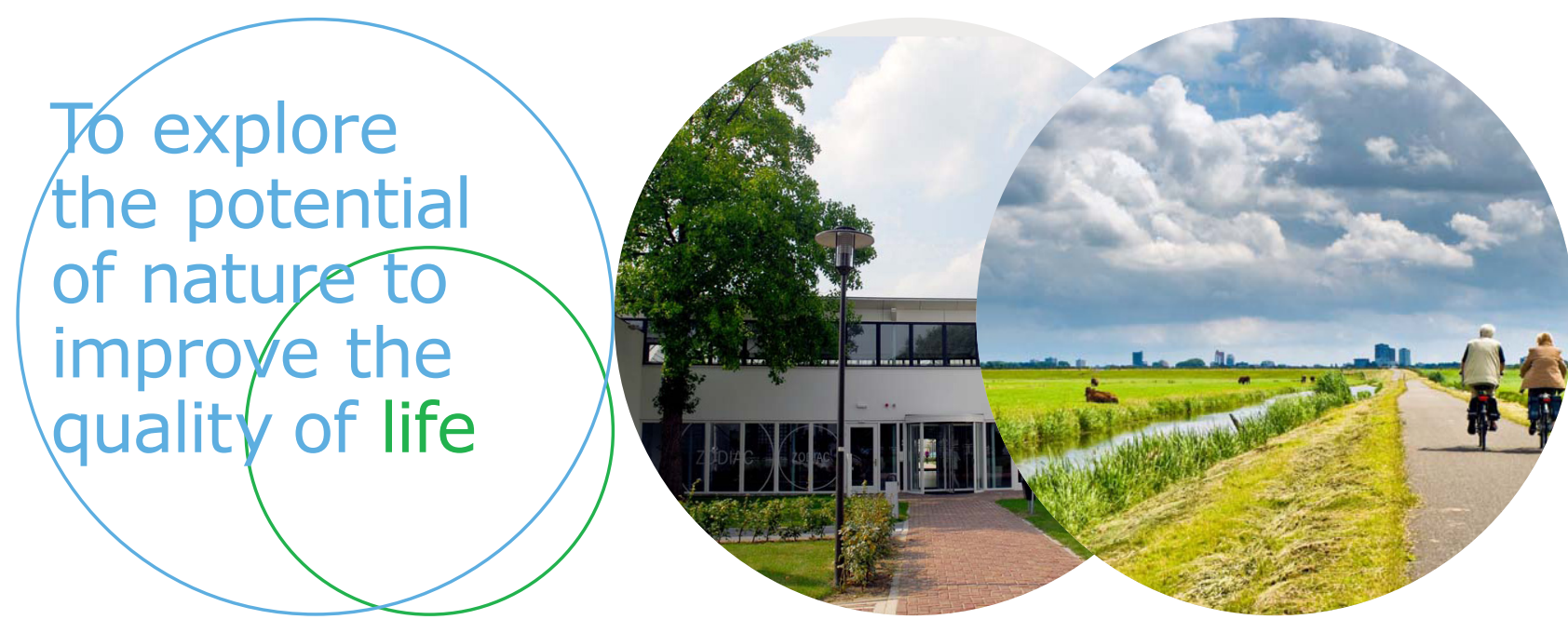

Wageningen Livestock Research Postbus 338

$6700 \mathrm{AH}$ Wageningen

T 0317483953

E info.livestockresearch@wur.nl www.wur.nl/livestock-research
Wageningen Livestock Research ontwikkelt kennis voor een zorgvuldige en renderende veehouderij, vertaalt deze naar praktijkgerichte oplossingen en innovaties, en zorgt voor doorstroming van deze kennis. Onze wetenschappelijke kennis op het gebied van veehouderijsystemen en van voeding, genetica, welzijn en milieu-impact van landbouwhuisdieren integreren we, samen met onze klanten, tot veehouderijconcepten voor de 21 e eeuw.

De missie van Wageningen University \& Research is 'To explore the potential of nature to improve the quality of life'. Binnen Wageningen UR bundelen 9 gespecialiseerde onderzoeksinstituten van stichting DLO en Wageningen University hun krachten om bij te dragen aan de oplossing van belangrijke vragen in het domein van gezonde voeding en leefomgeving. Met ongeveer 30 vestigingen, 6.000 medewerkers en 10.000 studenten behoort Wageningen UR wereldwijd tot de aansprekende kennisinstellingen binnen haar domein. De integrale benadering van de vraagstukken en de samenwerking tussen verschillende disciplines vormen het hart van de unieke Wageningen aanpak. 